\title{
Metodika zajištění kvality otevřených vzdělávacích zdrojů pro vysokoškolské vzdělávání
}

\author{
Eduard Petiška, Jana Dlouhá, Marie Pospíšilová, Jiří Dlouhý, Lucie Korhoňová
}

Envigogika 16 (2) - Metodiky / Methodologies

Published/ Publikováno 30. 12. 2021

DOI: http://doi.org/10.14712/18023061.63434

\begin{abstract}
Abstrakt
V rámci metodiky popisujeme jak správně využívat a vytvářet kvalitní otevřené vzdělávací zdroje (OER), přičemž se zaměřujeme na zdroje na bázi MediaWiki softwaru, jež se označují také jako wiki systémy. Zabýváme se také otázkou, jaké předpoklady pro tvorbu kvalitních online zdrojů je nutné zajistit, např. po stránce obsahu, práce redakčního týmu, technických parametrů prostředí atd. Metodika je určena jak těm, kdo vzdělávací materiály tohoto typu tvoří a chtějí se dozvědět jaké předpoklady by měly být splněny pro zajištění kvality, tak i těm, kdo tyto materiály užívají, vzhledem $\mathrm{k}$ tomu, že jim může pomoci při orientaci $v$ informačním prostředí.
\end{abstract}

\section{Klíčová slova}

Otevřené vzdělávací zdroje; MediaWiki software; zajištóvání kvality

\begin{abstract}
In the methodology, we describe how to properly use and create quality open educational resources (OER), we focused especially on resources based on the MediaWiki software. We deal with what prerequisites for the creation of quality online resources need to be provided, e.g. in terms of content, work of the editorial team, technical parameters of the environment, etc. The methodology can be used by those who create educational materials of this type as well as for those who use them because it can help them orient in the information environment.
\end{abstract}

\section{Key Words}

Open educational resources; MediaWiki software; ensuring quality 


\section{Metodika zajištění kvality otevřených vzdělávacích zdrojů pro vysokoškolské vzdělávání}

Centrum pro otázky životního prostředí, Univerzita Karlova v Praze

Oponenti:

- Doc. PhDr. Richard Papík, Ph.D., Ústav bohemistiky a knihovnictví, Filozoficko-přírodovědecká fakulta, Slezská univerzita v Opavě

- Mgr. Tamara Kováčová, Národní pedagogický institut České republiky

Datum vytvoření: březen 2021

Výsledek NmetS

Schváleno Ministerstvem práce a sociálních věcí, osvědčení č. 003-2021-COŽP, MPSV.

Metodika byla v červnu roku 2021 publikována na webových stránkách MPSV.

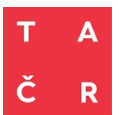

Tento dokument vznikl za podpory projektu programu Éta 2 Technologické agentury ČR

Metodika je výsledkem výzkumného projektu „Zajištění kvality otevřených vzdělávacích zdrojů: jak správně vytvářet a využívat volně dostupné studijní materiály" (TL02000013), řešeného v rámci programu Éta 2 Technologické agentury ČR v letech 2019-2021.

Obsah celého díla je licencovaný pod licencí CC BY ND - Uvedení autora a žádná odvozená díla. Výjimku tvoří ilustrace a další materiály, jež jsou licencovány pod licencí, pod níž byly zveřejněny. 


\section{Obsah}

$\begin{array}{ll}\text { Abstrakt } & 2\end{array}$

Obsah 3

Úvod

Cíle $\quad 6$

Otevřené vzdělávací zdroje $\quad 7$

Definice OER $\quad 9$

Otevřené licence $\quad 12$

$\begin{array}{ll}\text { Druhy OER } & 14\end{array}$

Principy pro zajištění kvality OER 16

Kritéria kvality pro vysokoškolské využívání OER 18

OER na bázi MediaWiki softwaru $\quad 23$

Ekonomické aspekty využívání a vytváření OER 26

Benefity a zápory OER MWS $\quad 29$

Specifický žánr textu 30

Wikipedie v kontextu zdrojů pro VŠ vzdělávání 33

Využívání OER MWS 34

Účely využívání 34

Využitelnost 36

Ověritelnost 36

Aktuálnost $\quad 38$

$\begin{array}{ll}\text { Nezaujatost } & 41\end{array}$

Vytváření OER MWS $\quad 43$

Žánr $\quad 43$

Obsah a uživatelé $\quad 43$

OER MWS, nebo Wikipedie? 43

Uvedení data a ID vytváření a editace $\quad 45$

Využívání hypertextu 45

Důsledné zdrojování 46

$\begin{array}{ll}\text { Mediální príloha } & 47\end{array}$

Cílová skupina $\quad 47$

$\begin{array}{ll}\text { Aktéři } & 48\end{array}$

Hierarchie $\quad 48$

Redakční tým $\quad 50$

Komunita $\quad 51$

Propagace zdroje $\quad 52$

Otevřenost 52

Motivace $\quad 52$

Ocenění $\quad 52$

Uvádění autorství 53 
Uvádění recenzenta 53

Statistické údaje $\quad 53$

Kvalita obsahu $\quad 54$

Garant kvality $\quad 54$

Vnímání kvality $\quad 54$

Rozpoznání kvality $\quad 55$

Spolehlivost informací $\quad 55$

Aktuálnost informací $\quad 55$

Percepce kvality studenty $\quad 56$

Procesy zajištění kvality 56

Rizikové faktory $\quad 57$

Technické parametry prostředí 58

$\begin{array}{ll}\text { Internacionalizace a lokalizace } & 58\end{array}$

Instalace a konfigurace $\quad 58$

Úpravy rozhraní 58

Bohatý obsah $\quad 58$

Sledování úprav $\quad 59$

Navigace $\quad 59$

$\begin{array}{ll}\text { Organizace obsahu } & 59\end{array}$

Závěr 61

$\begin{array}{ll}\text { Seznam použitých zkratek } & 62\end{array}$

Seznam metodických výstupů přidružených

k metodice

Seznam dosavadních publikačních výstupů řešitelů v dané oblasti předcházející metodice

$\begin{array}{ll}\text { Literatura } & 67\end{array}$

$\begin{array}{ll}\text { Seznam použité literatury } & 67\end{array}$ 


\section{Úvod}

Předkládaná metodika popisuje jak správně využívat a vytvářet otevřené vzdělávací zdroje (anglicky: Open Educational Resources - OER) ${ }^{1}$.

Informační prostředí se v současné době mění rychleji než dříve. Informační média a žánry, které existovaly po stovky let, nyní prochází značnou změnou a vznikají také média a žánry nové. Domníváme se, že tyto změny jsou tak rychlé, že nejsou dostatečně podchyceny vědeckým výzkumem ani zohledňovány při tvorbě politik. Nové mediální formáty pritom značně mění způsob komunikace a života. Správně je využívat je proto výzvou pro všechny aktéry činné v oblasti komunikace poznatků.

S postupující digitalizací a přesunem různých aspektů našich životů do digitálního prostředí roste i význam nových komunikačních formátů. Pro generaci $Z$ (narození zhruba od poloviny devadesátých let) a generaci Alpha (narození přibližně od roku 2010), které již vyrostly s digitálními technologiemi v ruce, mohou být konvenční metody komunikace, jako jsou tištěné knihy či papírová skripta, vnímány jako nepohodlné a nepraktické. Neposkytují onen uživatelský komfort, kterými se vyznačují zdroje digitální, tedy například okamžitý přístup, fulltextové vyhledávání či snadnost aktualizace a sdílení, případně modifikace obsahu.

V současnosti probíhá podstatná změna v přistupu ke vzdělávacím materiálům. Mezi novými médii v komunikaci poznatků pro vzdělávací účely dominuje koncept tzv. otevřených vzdělávacích zdrojů (OER). Jako OER jsou označovány ty formy nových médií, které podporují určitou otevřenost v oblasti přístupu k obsahu. Tyto zdroje jsou většinou digitální. Obecně panuje shoda na tom, že zdroje označované jako OER umožňují volně využívat, upravovat a sdílet studijní materiály.

Mezi hlavní výzvy v oblasti OER patří problém jak se rychle orientovat v množství informací; s tím souvisí dosud chybějící široce akceptovaná pravidla pro zajištění kvality $v$ této oblasti. $V$ problematice OER totiž můžeme také hovořit o změně žánru vzdělávacího média, které se v mnoha ohledech liší od klasických skript. OER obecně vzato umožňují větší participaci na tvorbě obsahu vzhledem k tomu, že eliminují vysoké transakční náklady na publikaci výstupu. Vytvářet je může každý a někdy - jako v prípadě OER fungujících na bázi MediaWiki softwaru - může kdokoliv i jednoduše modifikovat ke svému účelu ty již vytvořené. S tím právě souvisí otázka jak odlišit kvalitní zdroje od těch méně kvalitních a jaká kritéria při tomto hodnocení používat. Tomu se také bliže věnujeme ve specifických kapitolách této metodiky.

\footnotetext{
${ }^{1}$ Za účelem jednotnosti používáme i v českém textu pro otevřené vzdělávací zdroje zkratku OER.
} 
Zároveň se ukazuje, že studenti přestávají používat učebnice a studují z volně dostupných zdrojů na internetu (Petiška, 2018a,b). Učitelé tak často již mohou ztrácet přehled, z čeho všeho se jejich studenti vlastně učí a s jakými informacemi se pritom setkávají. Zatímco například ve Spojených státech amerických se o těchto zdrojích vede společenská diskuze a některé školy je již začínají využívat jako alternativu klasických textů, v České republice je zájem vzdělávacích institucí poměrně slabý.

Ukazuje se také, že jednou z největších překážek při implementaci OER do vzdělávání je právě již zmiňovaný problém se zajištěním kvality těchto zdrojů. Existuje nepoměr mezi pravidly používanými pro „uzavřené” zdroje (tištěné i elektronické) a nedostatkem pravidel pro OER. Informační prostor je přitom zahlcen dezinformacemi, jež mají často stejnou, ne-li vyšší popularitu než informace ze seriózních zdrojů.

OER nabízí největší potenciál pro aplikaci ve vysokém školství. Zároveň zde ale chybí metodický nástroj, který by popisoval jak vytvářet zdroje, jež by splňovaly požadavky pro vysokoškolskou výuku, popř. popsal jejich specifika. Tento nástroj může být užitečný vzdělávacím institucím při tvorbě těchto zdrojů, jejich tvorba pak může ušetřit značné prostředky z veřejných zdrojů, snížit transakční náklady přenosu poznatků a zároveň pomoci studentům snižit jejich náklady na studium.

Předkládaná metodika reaguje na tuto potřebu; jejím cílem je úvod do problematiky otevřených vzdělávacích zdrojů a doporučení pro jejich správné využívání a vytváření. Mưže tak posloužit nejen potenciálním tvưrcům, ale i uživatelům těchto zdrojů. Při vytváření metodiky jsme využili metodu analýzy aktérů otevřených vzdělávacích zdrojů na bázi MediaWiki softwaru (OER MWS), které jsou provozovány na Univerzitě Karlově, stejně jako analýzu těchto zdrojů. ${ }^{2}$ Co se týče rozsahu platnosti metodiky, zaměřujeme se zejména na otevřené vzdělávací zdroje na bázi MediaWiki softwaru, a to v českém vysokoškolském kontextu, zejména na Univerzitě Karlově, na níž jsme OER také zkoumali. Právě výsledky tohoto výzkumu tvoří podklad, na němž tato metodika vznikla. Naše výsledky mohou mít ale také obecnější platnost pro jiné typy OER a na jiných stupních vzdělávání, což však v této metodice nezajišt'ujeme.

\section{Cíle}

Cílem této metodiky je zejména:

- Uvést do problematiky otevřených vzdělávacích zdrojů - zejm. těch, jež fungují na bázi MediaWiki softwaru. Na tyto zdroje jsme se zaměřili vzhledem

\footnotetext{
${ }^{2}$ Podrobnější popis metody a výsledků výzkumu viz článek Petiška a kol., 2020.
} 
$\mathrm{k}$ jejich popularitě u studentů, stejně jako specifickým možnostem, díky nimž jsou zajímavé pro vytváření vzdělávacích materiálů v rámci vysokoškolského vzdělávání.

- Popsat zásady jejich využívání.

- Poskytnout metodickou oporu při jejich vytváření.

\section{Otevřené vzdělávací zdroje}

„,Hnutí za otevřené vzdělávací zdroje stojí na jednoduché

a mocné myšlence, že znalosti jsou veřejný statek.

A technologie obecně, zejména však internet, umožňuje

každému jedinečnou príležitost sdílet a užívat tyto znalosti."

Mike Smith (Wiley, 2014)

Otevřené vzdělávací zdroje jsou důležitým fenoménem v oblasti vzdělávání. Umožňují volně širìit, vytvářet a využívat studijní materiály, přičemž se dá očekávat, že jejich význam bude narůstat. Tyto zdroje mají značný potenciál pro využití ve vysokém školství, pokud bude dostatečně zajištěna jejich kvalita.

Problematika OER se diskutuje a zkoumá převážně v západních zemích, především pak $v$ USA. Tam je toto téma zvláště relevantní vzhledem $k$ vysokým cenám učebnic a nákladům na vzdělávání obecně. Vytváření těchto zdrojů proto podporují jak přední americké univerzity, tak soukromé nadace. Oproti tomu v České republice se termín OER na vysokých školách ve srovnání s mezinárodním kontextem použivá málo (Kapitulčinová a kol., 2015) a celkově můžeme konstatovat, že i přes různé strategie a některé úspěšné projekty není této problematice ze strany relevantních aktérů věnována větší pozornost. Správné uchopení a podpora těchto zdrojů může přitom přispět $\mathrm{k}$ transferu znalostí mezi různými aktéry, diseminaci poznatků napříč společností a podpořit jak třetí roli vysokých škol ve veřejném životě ${ }^{3}$, tak přispět k vytváření znalostní společnosti.

Mezi výhody, které otevřené vzdělávací zdroje poskytují, patří např. snadná aktualizace, úspora prostředků při jejich vytváření a aktualizaci. Proces jejich výroby, distribuce a celý životní cyklus je nejen finančně úspornější, ale i šetrnější k životnímu

\footnotetext{
${ }^{3}$ Vytváření volně dostupných otevřených vzdělávacích zdrojů v rámci univerzit pomáhá šírit poznatky i mimo ně, a tak přispívá k šíření akademických poznatků ve společnosti.
} 
prostředí a studentům šetří značné prostředky za studijní materiály (Hilton, 2016). Vedou se proto diskuze o možnostech jejich institucionální podpory. Používání OER ale také přináší řadu otázek a problémů (Hylén, 2006):

- Udržitelnost (tedy spolehlivost v průběhu času) - Nestačí vytvořit OER, tyto zdroje by měly být také pravidelně aktualizovány nejnovějšími poznatky.

- Duševní vlastnictví a autorská práva - Mnoho tvưrců a uživatelů OER nemá dostatečné zkušenosti s legislativou duševního vlastnictví a licencemi. Pokud jsou tyto zdroje uveřejněny pod licencí, která neumožňuje jejich bezplatnou distribuci, není možné je označit jako OER (viz dále Definice OER).

- Problém s kvalitou - OER mají různou kvalitu, často nejsou uvedena kritéria kvality a/nebo garant kvality.

- Interoperabilita (provázanost různých systémů) - Základním principem OER je jejich volné využívání a modifikace. Každý systém OER by proto měl být interaktivní a umožňovat spolupráci pro propojení informací z různých odvětví, což je však často v rozporu s omezeními, která představuje duševní vlastnictví. 


\section{Definice OER}

Termín otevřené vzdělávací zdroje se používá jako označení pro volně přístupné materiály, které je možné využít ke studiu. Objevuje se v různých kontextech. Obecně ale panuje shoda, že zdroje, které je možné označit jako OER, by měly umožnit uživatelům nejen prístup ke vzdělávacím materiálům, ale i jejich šiření a modifikaci.

Jedna z hlavních autorit v oblasti podpory OER, americká nadace Hewlett Foundation, definuje tyto zdroje následovně: „Otevřené vzdělávací zdroje jsou výukové, učební a výzkumné materiály v jakémkoli médiu - digitálním nebo jiném, které jsou umístěny ve veřejné doméně nebo byly uvolněny $v$ rámci otevřené licence, která umožňuje přistup, použití, přizpůsobení a redistribuci jinými uživateli s žádným nebo limitovaným omezením" (Hewlett Foundation, 2019). Významný výzkumník v oblasti OER, David Wiley (2014), uvádí několik rysů, které by zdroj měl splňovat, aby se dal označit za OER ${ }^{4}$.

- Opětovné právo využití.

- Revize - právo přizpůsobit, upravovat nebo měnit obsah samotný (např. překládat obsah do jiného jazyka).

- Remix - právo zkombinovat původní nebo upravený obsah s jiným obsahem a vytvořit tak něco nového.

- Distribuce - právo sdílet kopie původního obsahu, revizí nebo remixů s ostatními (např. za účelem poskytnutí kopie obsahu př́teli).

- Uchování - možnost si obsah stáhnout a uložit.

Na základě stávajícího výzkumu, literatury a definic dospívá Wiley k závěru, že OER jsou takové vzdělávací materiály, „které používají licence Creative Commons, které existují ve veřejném vlastnictví a jsou volně k dispozici bez omezení” (Wiley, 2014). Ačkoliv se různé definice částečně liší a pojem může být používán pro různé materiály, můžeme konstatovat, že panuje shoda, že OER jsou materiály, které je možné bezplatně nejen využívat k osobní potřebě, ale i šírit a modifikovat (viz Tabulka 1).

\footnotetext{
${ }^{4}$ Tato pravidla se označují jako tzv. „4 R” - Reuse, Revision, Remix, Redistribution; později bylo prìdáno uchování (Retain) a koncept se změnil na „5R”.
} 
Tabulka 1. Přehled jednotlivých definic a jejich společných znaků (What is OER, 2016)

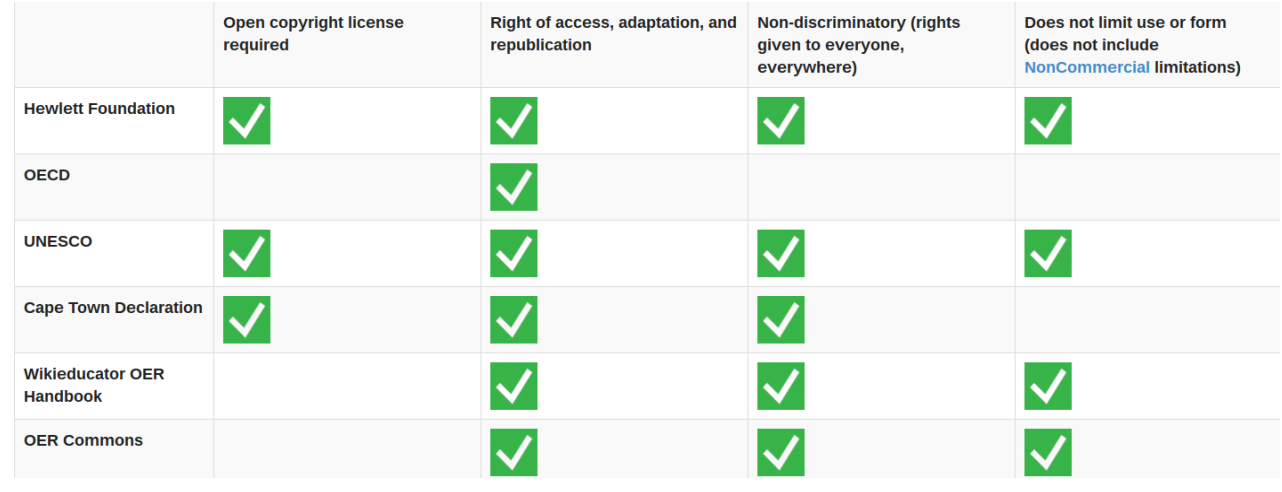

Různé pojmy - jako otevřený přístup (open access) a otevřený obsah (open content) -, které se používají jako označení pro znalosti volně přístupné všem, sice sdílí myšlenku „otevřené znalosti”, neznamenají ale to samé (viz Obrázek 1). Z výše uvedeného plyne, že ne vše, co je volně dostupné na internetu a dá se použít ke vzdělávacím účelům, je OER. Naopak využití některých zdrojů, které jsou k dispozici ke stažení, může být neetické, či prímo nelegální. Jako př́klad můžeme uvést různé otázky ke zkouškám a studijní materiály nahrávané studenty na komerční úložiště (Dlouhá a kol., 2015) nebo studijní materiály jako skripta či monografie, které sice vznikly na vysokých školách za veřejné peníze, ale byly do různých cloudů nahrány nelegálně bez svolení příslušné autority, a tím porušují autorský zákon.

Obrázek 1. Přehledové schéma různých pojmů, jejichž spojující myšlenkou je otevřená znalost (Onaifo, 2016)

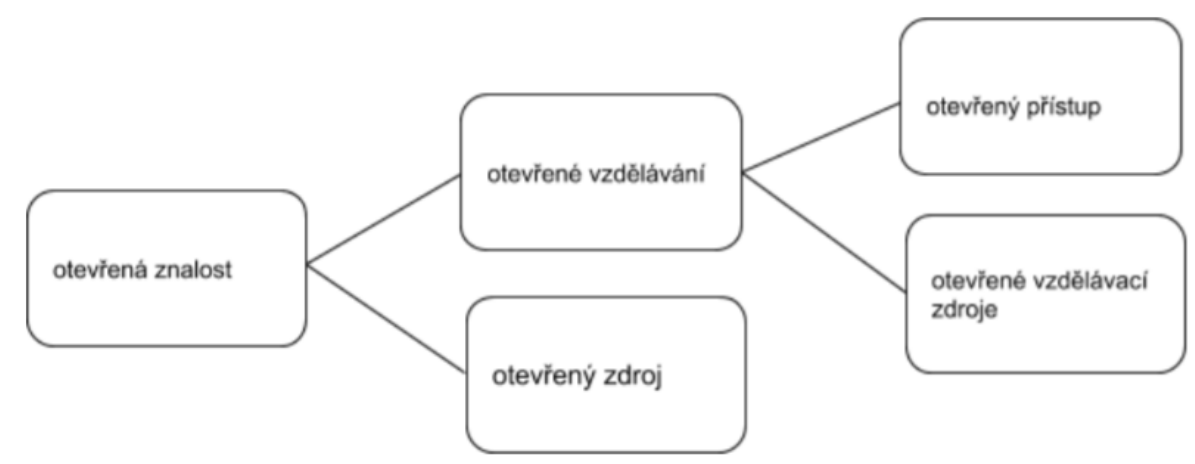

Za OER je tedy problematické označit všechny zdroje, které jsou volně k dispozici at' již v tištěné, či digitální podobě, ale mají takový copyright, který jejich volné využívání z principu nepovoluje, či copyright nemají vyznačený vůbec. Jejich jakékoliv sdílení (např. na osobních stránkách) pak již může představovat porušení zákona či přinejmenším vyvolává etické problémy a otázky typu: „Co je dovoleno, a co již ne?” 
Pro účely této metodiky chápeme OER ve shodě s výše uvedeným vymezením, tedy jako materiály, které jsou nejen volně dostupné at' již v tištěné, či digitální podobě, ale umožňují také sdílení a modifikaci (tedy vytvoření vlastního díla na jejich základě). Za OER proto považujeme všechny zdroje, které jsou uvedeny pod otevřenou licencí, která výše zmíněné umožňuje. 


\section{Otevřené licence}

Otevřená licence (anglicky: public license či public copyright license) je takový druh licence, který umožňuje otevřenější přístup k obsahu, než je zvykem u tradičních licencí. Zejména opravňuje jakéhokoliv uživatele $\mathrm{k}$ užití díla bez nutnosti uzavírat $\mathrm{s}$ autorem samostatnou licenční smlouvu. Otevřené licence se používají, když autor chce dát jiným lidem právo sdílet, používat i jinak využívat práci, kterou vytvořil. Podmínky užití jsou přitom specifikovány v rámci zvolené licence. Ačkoliv existuje několik druhů standardizovaných druhů otevřených licencí, zdaleka nejpopulárnějšími se staly licence Creative Commons, které jsou také nejvyužívanějším typem licencí pro otevřené vzdělávací zdroje.

Tabulka 2. Přehled základních typů nejvyužívanějších otevřených licencí Creative Commons ${ }^{5}$

\begin{tabular}{|c|c|c|}
\hline Označení & Popis & Zkratka \\
\hline (c) $\boldsymbol{z}_{\text {zERo }}$ & Nejširší možné užití díla (i bez uvedení autorství) & 0 \\
\hline (c) & Pouze uvedení autora & BY \\
\hline 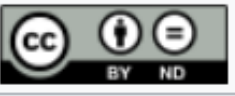 & Uvedení autora + Žádná odvozená díla & BY-ND \\
\hline (c) & Uvedení autora - týká se původního díla i jeho modifikací & BY-SA \\
\hline (c) (4) (5) & Uvedení autora + Pouze nekomerční užití & BY-NC \\
\hline (c) (4) $(3)$ & Uvedení autora + Pouze nekomerční užití + Žádné modifikace & BY-NC-ND \\
\hline (c) (7) (3) (2) & Uvedení autora + Nekomerční užití + Zachovejte licenci & BY-NC-SA \\
\hline
\end{tabular}

Licence Creative Commons (CC) je jednou z několika otevřených licencí týkajících se autorského práva, které umožňují bezplatnou distribuci jiného díla, jež by jinak bylo chráněno autorskými právy. Škála různých typů CC (viz Tabulka 2) dává autorům různé možnosti (například když se rozhodnou povolit pouze nekomerční užití daného díla) a zbavuje ty, kteří používají nebo distribuují autorovo dílo, obav z porušení autorských práv, pokud dodržují podmínky uvedené v licenci, pod níž autor umožnil využívat svoje dílo. Licence se liší podle různých podmínek, které umožňuji využívání. Nejnovější je verze 4.0. Všechny licence stojí na několika základních prvcích (viz Tabulka 3 ). ${ }^{6}$

Tabulka 3. Popis základních prvků licencí Creative Commons ${ }^{7}$

\footnotetext{
${ }^{5} \mathrm{https}: / / \mathrm{cs}$.wikipedia.org/wiki/Creative Commons

${ }^{6}$ https://en.wikipedia.org/wiki/Creative Commons license

7 https://en.wikipedia.org/wiki/Creative Commons license
} 


\begin{tabular}{|c|c|c|}
\hline Obrázek & Práva & Popis \\
\hline & $\begin{array}{l}\text { Přidělení } \\
\text { (BY) }\end{array}$ & $\begin{array}{l}\text { Držitelé licence mohou kopírovat, distribuovat, zobrazovat a pracovat } \\
\text { s dílem a vytvářet odvozená díla a remixy založené na něm pouze tehdy, } \\
\text { pokud uvádějí autora nebo poskytovatele licence tak, jak oni specifikují. }\end{array}$ \\
\hline & $\begin{array}{l}\text { Podobné } \\
\text { sdílení (SA) }\end{array}$ & $\begin{array}{l}\text { Držitelé licence mohou distribuovat odvozená díla pouze na základě } \\
\text { licence shodné (,ne více restriktivní) s licencí, pod kterou je licencováno } \\
\text { původní dílo. Bez tohoto opatření mohou být deriváty (práce vzniklé na } \\
\text { základě původního díla) sublicencovány s kompatibilními, ale } \\
\text { restriktivnějšími licenčními doložkami (např. z CC BY na CC BY-NC), jež } \\
\text { poskytují možnost upravit původní dílo, které je možné využít i ke } \\
\text { komerčním účelům, na dílo, které je sice možné sdílet, ale není možné ho } \\
\text { využít ke komerčním účelům. }\end{array}$ \\
\hline & $\begin{array}{l}\text { Nekomerční } \\
\text { (NC) }\end{array}$ & $\begin{array}{l}\text { Držitelé licence mohou kopírovat, distribuovat, zobrazovat a pracovat } \\
\text { s dílem a vytvářet odvozená díla a remixy na něm založené pouze pro } \\
\text { nekomerční účely. }\end{array}$ \\
\hline & $\begin{array}{l}\text { Žádné } \\
\text { deriváty } \\
\text { (ND) }\end{array}$ & $\begin{array}{l}\text { Držitelé licence mohou kopírovat, distribuovat, zobrazovat a pracovat } \\
\text { pouze s původní kopií díla, nikoliv s deriváty a remixy, které na jeho základě } \\
\text { vznikly. }\end{array}$ \\
\hline
\end{tabular}




\section{Druhy OER}

Ze současných definic plyne, že za otevřený vzdělávací zdroj můžeme tedy označit prakticky jakýkoliv zdroj, který je licencován pod otevřenou licencí a je možné ho nějakým způsobem využít ke vzdělávacím účelům.

Toto označení je nicméně tak široké, že za otevřený vzdělávací zdroj je možné označit takřka cokoliv. Pod otevřenou licencí nacházíme nejrůznější typy obsahu, jež je označují za OER. Nejedná se tedy pouze o text, ale také o videa, audionahrávky, fotografie, obrázky a veškeré další formy, které se dají využít ke vzdělávacím účelům. OER mohou představovat jak otevřené vzdělávací kurzy, tzv. MOOC (Massive Open Online Courses), interaktivní učebnice, Wikipedie a další wiki systémy, tak i různé dokumenty $v$ cloudech či výsledný produkt převodu jakéhokoliv fyzického média do digitálního (např. digitalizovaná skripta). $\mathrm{Na}$ základě našeho výzkumu se domníváme, že je možné definovat tři základní typy OER:

- Audiovizuální materiál - Jedná se zejména o videa, online kurzy, ale také o různé formy interaktivních médií jako např. knihy atd.

- Ostatní zdroje - Pdf nahraná do cloudu, digitalizovaná skripta, veškerý materiál převedený z fyzické podoby do digitální.

- Wiki systémy (kterým se věnujeme dále).

Textové formy OER mohou mít v online prostředí stejnou strukturu a podobu jako klasické tištěné zdroje ( $v$ případě, že se zdroj pouze převede do digitálního formátu a umístí $v$ online úložišti, např. ve formě pdf.). Ale mohou také umožňovat jeho snadnou modifikaci uživateli prímo $v$ prostředí daného úložiště (viz dále OER fungující na bázi MediaWiki softwaru). Podobu tištěných zdrojů mají také tzv. otevřené učebnice, které jsou zamýšleny primárně k distribuci v online prostoru s tím, že si je zájemci mohou sami vytisknout, popř. upravit pro svoje účely. Mezi nejznámější otevřené učebnice patři OpenStax ${ }^{8}$, které jsou také ukázkovým př́kladem dobré praxe zajištění kvality OER, nebot' jsou vytvářeny a recenzovány množstvím expertů na danou problematiku. OpenStax jsou podporovány americkými nadacemi, jako je např. Bill and Melinda Gates Foundation. ${ }^{9}$

Kromě textové formy je druhým nejčastějším typem OER audiovizuální materiál, zejm. obrázky (fotografie) a videa. Obrázky a fotografie jsou cenným doplňkem textových forem těchto zdrojů, pokud slouží pro ilustraci konkrétní problematiky. Videa jsou pak oporou distančních kurzů, pro něž se vžilo označení MOOC (Massive Open Online Course). Při

\footnotetext{
${ }^{8}$ https://openstax.org/

${ }^{9}$ Podle odhadů ušetří využívání otevřených učebnic OpenStax v akademickém roce 2016/2017 na Rice University studentům 70 milionů dolarů. https://www.enviwiki.cz/wiki/Otev\%C5\%99en\%C3\%A1 u\%C4\%8Debnice
} 
splnění podmínek těchto kurzů je možné navíc obdržet doklad o jejich absolvování (certifikát). Jedny z prvních MOOC začaly vznikat na Massachusettském technologickém institutu (MIT). Mezi nejznámější portály současnosti, na nichž jsou tyto kurzy k dispozici často zdarma, pak patří Edx a Coursera. Ukazuje se ale také, že tyto kurzy využívají často uživatelé, kteří jsou již vysokoškolsky vzdělaní (Rohs \& Ganz, 2015). Nenahrazují tedy vysokoškolské vzdělání, spíše slouží pro specializaci. Proto je také při jejich vytváření vhodné přihlédnout ke specifickým potřebám cílové skupiny a zaměřit je spíše na konkrétní problémy než na všeobecný úvod.

Mezi nejvyužívanější zdroje, jež se dají označit za OER, patří známá Wikipedie. Ta je provozována na MediaWiki softwaru, který také zpopularizovala a jež se následně začal využívat i pro tvorbu dalších OER. Zdroje na bázi MediaWiki softwaru jsou často ze své podstaty (open source software) pod otevřenou licencí, splňují proto požadavky kladené na OER (šíření a upravování). Kromě textu umožňují také vkládání obrázků, videí či zvukových souborů jako doplňků textu. 


\section{Principy pro zajištění kvality OER}

Otázka kvality představuje problém jak u digitálních zdrojů, tak i u OER. Kvalita OER je navíc jednou z nejčastěji diskutovaných otázek v rámci problematiky těchto zdrojů a představuje také překážku v jejich využívání. Zejména OER fungující na bázi Mediawiki softwaru jsou značnou výzvou po stránce zajištění kvality, často totiž umožňují zapojení do vytváření materiálů i neregistrovaným uživatelům, a může je tak vytvářet prakticky každý. Nízká kvalita některých zdrojů ovlivňuje postoj k nim jako celku, proto panuje jistá nedůvěra $\mathrm{k}$ využívání OER ke vzdělávacím účelům.

Tato nedůvěra bývá často oprávněná. Termín otevřené vzdělávací zdroje se totiž používá jako označení pro poměrně různorodou směs úložišt' informačních materiálů na internetu. Nelze o nich a o jejich kvalitě hovorit per se, protože mohou variovat od osobních blogů, kde neznámí autoři prezentují své názory, až po vysoce kvalitní materiály, jakými jsou recenzované odborné články. Situaci komplikuje skutečnost, že neexistují standardy (kritéria) kvality, které by byly tvưrci či uživateli OER obecně uznávané. Vždy je proto třeba posuzovat konkrétní zdroj (úložiště), či ještě lépe každý materiál na něm jednotlivě - a to zvláště v těch př́padech, kdy chybí oficiální garant kvality (např. respektovaný autor či instituce). Problematika kvality OER se dá rozdělit do čtyř oblastí:

- prostředí daného systému,

- obsahová stránka,

- formální a etické atributy kvality,

- uživatelská hlediska.

Pro prostředí daného systému můžeme definovat kritéria ve smyslu zajištění jeho fungování po technické stránce (např. jak je zajištěna a vyznačena kvalita, kdo daný zdroj může editovat, jak je zajištěna jeho udržitelnost a aktualizace materiálů, zda je možné uvedení garanta kvality - autora či recenzenta; viz Tabulka 4). Je třeba upozornit na skutečnost, že zdroj sice může splňovat kritéria kvality technického prostředí, avšak nemusí obsahovat kvalitní texty ke studiu. Pokud se hovoří o kvalitě OER, myslí se tím především kvalita obsahu. Právě tato otázka však představuje značný problém. Její zodpovězení ve smyslu „Je daný zdroj kvalitní?" vyžaduje obsahovou analýzu, která je ovšem obtižná jak z hlediska časové náročnosti, tak nalezení relevantních odborníků, kteří by ji mohli provést například formou recenzního řízení. ${ }^{10}$

\footnotetext{
${ }^{10}$ Problém hodnocení kvality OER oproti klasickým textům spočívá nejen v tom, že u nich často chybí garant kvality (tak jako v př́padě Wikipedie), ale i v tom, že se dají jednoduše aktualizovat. Právě to představuje dvojsečnou zbraň. Tento aspekt může pomoci kvalitě obsahu tím, že jej aktualizuje o nejnovější poznatky. Na druhou stranu ovšem právě lehkost aktualizace může svádět $k$ jisté laxnosti ohledně tvorby obsahu - když někdo upozorní na chybu, dá se jednoduše opravit. Pokud je zdroj
} 
Při takové analýze se mohou brát v potaz různé aspekty kvality, jako např. komplexita textu - ve smyslu zahrnutí různých aspektů a úhlů pohledu, aby byl poskytnut vyvážený názor (je dostatečně komplexní?). Dále jak zpracování (je dobře stylisticky, gramaticky a vizuálně zpracován?), tak věrohodnost (ověřitelnost informací respektovanými zdroji). Některé tyto aspekty jsou pritom subjektivní, a to nejen ve smyslu subjektivního názoru experta, ale i ve smyslu pohledu studenta, který zdroj využívá (např. jiný požadavek na komplexitu má student prvního ročníku bakalářského studia VŠ a jiný doktorand).

Tabulka 4. Postupy hodnocení kvality obsahu OER, které charakterizuje sociální a technologický aspekt (dle Clements et al., 2015, viz též vložené reference). Pro konkrétní příklady jednotlivých př́stupů k hodnocení kvality viz jednotlivé studie.

\begin{tabular}{|l|l|}
\hline $\begin{array}{l}\text { Př́stup k hodnocení } \\
\text { kvality }\end{array}$ & Reference \\
\hline $\begin{array}{l}\text { Peer review } \\
\text { systém/hodnocení } \\
\text { kvality uživateli, } \\
\text { většinou na Likertověn } \\
\text { škále (1-5) }\end{array}$ & $\begin{array}{l}\text { Atenas and Havemann, 2014, Larsen and Vincent-Lancrin, 2005, Schuwer et } \\
\text { al., 2009, Catteau et al., 2008, Li, 2010, Krauss and Ally, 2005, Sanz- } \\
\text { Rodriguez et al., 2010, Sampson and Zervas, 2013, Currier et al., 2004 } \\
\text { Zervas et al., 2014, Liddy et al., 2002, Waaijers and van der Graaf, 2011, } \\
\text { Venturi and Bessis, 2006, Zhang et al., 2004 }\end{array}$ \\
\hline $\begin{array}{l}\text { Nástroje na hodnocení } \\
\text { kvality uživateli (např. } \\
\text { LORI) }\end{array}$ & $\begin{array}{l}\text { Atenas and Havemann, 2014, Clements and Pawlowski, 2012, Downes, 2007, } \\
\text { Richter and Ehlers, 2010, Atkins et al., 2007, Sinclair et al., 2013, Vargo et al., } \\
\text { 2003, Defude and Farhat, 2005, Kumar et al., 2005, Alharbi et al., 2011 }\end{array}$ \\
\hline $\begin{array}{l}\text { Nástroje } \\
\text { doporučení } \\
\text { zdroje) }\end{array}$ & $\begin{array}{l}\text { Manouselis et al., 2013, Atenas and Havemann, 2014, Pegler, 2012, Petrides } \\
\text { et al. (2008), Adomavicius and Tuzhilin, June 2005, Duffin and Muramatsu, } \\
\text { 2008, Manouselis and Sampson, 2004, Manouselis et al., 2011, Li, 2010, } \\
\text { Sanz-Rodriguez et al., 2010, Sabitha et al., 2012, Sampson and Zervas, 2013, } \\
\text { Zervas et al., 2014 }\end{array}$ \\
\hline $\begin{array}{l}\text { Komentování } \\
\text { Minguillón et al., 2010, Catteau et al., 2008, Li, 2010, Vargo et al., 2003, Sanz- } \\
\text { Rodriguez et al., 2010, Sampson and Zervas, 2013, Waaijers and van der } \\
\text { Graaf, 2011 }\end{array}$ \\
\hline
\end{tabular}

tištěný, můžeme na něj jednoduše odkazovat, jak na stranu, tak na vydání dané publikace (první, druhé). U OER je situace složitější, strany se mohou měnit, stejně tak obsah celého textu. U mnoha zdrojủ nestačí citovat pouze čas př́stupu. Napríiklad u Wikipedie může proběhnout více než jedna editace $v$ rámci jedné minuty. Vhodnější je proto citovat specifické číslo stránky (ID). Není to ale běžná praxe. 


\begin{tabular}{|l|l|}
\hline Oblíbené & $\begin{array}{l}\text { Minguillón et al., 2010, Sanz-Rodriguez et al., 2010, Sampson and Zervas, } \\
\text { 2013, Zervas et al., 2014 }\end{array}$ \\
\hline Sociální označování & Minguillón et al., 2010, Stacey, 2007, Sampson and Zervas, 2013 \\
\hline $\begin{array}{l}\text { Označování } \\
\text { (nahlašování } \\
\text { nefunkčních odkazů, } \\
\text { nevhodného obsahu } \\
\text { atd.) }\end{array}$ & Sinclair et al., 2013, Clements and Pawlowski, 2012 \\
\hline
\end{tabular}

\section{Kritéria kvality pro vysokoškolské využívání OER}

Využívání OER může mít negativní dopad na výslednou podobu znalostí studentů (pokud jim nejsou doporučeny kvalitní zdroje či nejsou vedeni k tomu je rozeznat). Některá kritéria kvality (z pohledu uživatele) jsou studenty snadno rozpoznána, na jejich základě pak daný zdroj (ne)využívají. Obsahová kritéria však nemusí umět rozpoznat.

Výzkum realizovaný v USA poukázal na skutečnost, že středoškolští a vysokoškolští studenti, i když se běžně pohybují v digitálním prostředí, mají problém rozeznat kvalitní informace. Více než 80 \% jich například věří, že reklamní sdělení je oficiální novinová zpráva. Mají také problémy s hodnocením zpráv na Twitteru i u dalších sdělení (Wineburg a kol., 2016). To může být ovlivněno množstvím volně dostupných informací rozdílné kvality a nedostatečných kompetencí ji posoudit. Výsledky výzkumu mezi českými vysokoškolskými studenty environmentálních oborů ukázaly, že značná část není schopna definovat kritéria kvality (t.j. neuvedli ani jedno kritérium). Mezi těmi, kteří kritéria uvedli, převažovaly nejčastěji odpovědi, jež se daly zařadit do kategorie „práce se zdroji”, „věrohodnost (ověřitelnost)” a „přehlednost” (Obrázek 2). 
Obrázek 2. Graf znázorňující jednotlivé kategorie kritérií kvality, jimiž se studenti podle svých odpovědí řídí při posuzování kvality OER. Počet respondentů: 233 (Petiška, 2018a)

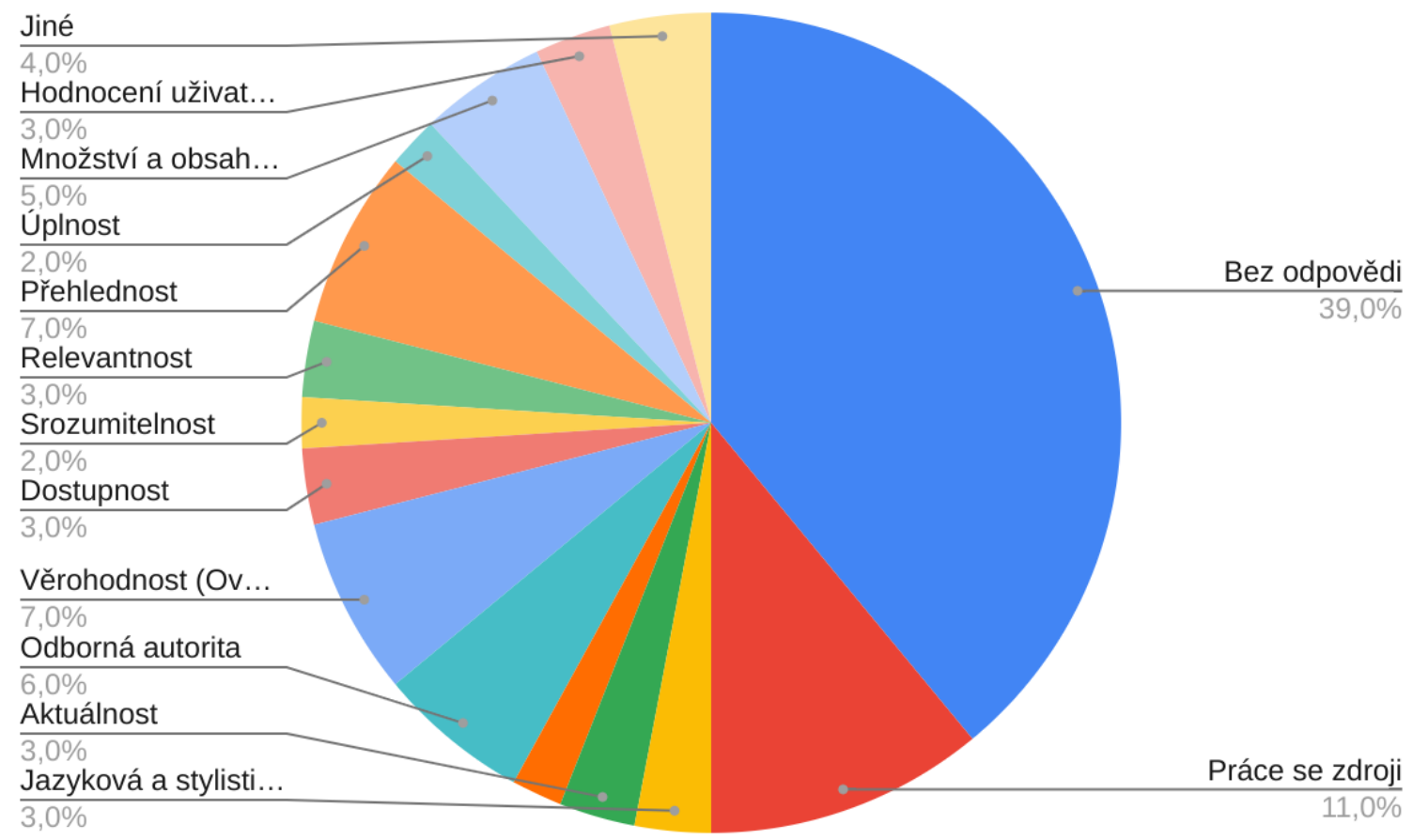

Yaari a kol. (2011) zkoumali, které atributy kvality jsou relevantní pro uživatele Wikipedie, jejich respondenti jako atributy kvality uvedli množství informací, spokojenost s obsahem a externí odkazy. Naopak atributy jako počet editací a počet unikátních editorů získaly protichůdné významy - „jako atributy kvalitních článků bylo zmíněno jak málo editací/editorů, tak i mnoho editací/editorů". Právě Wikipedie (anglická verze) má podrobně rozpracovaný systém hodnocení kvality z hlediska uživatelů, kteří hodnotí jednotlivé články z hlediska různých aspektů kvality (Přispěvatelé Wikipedie, 2021) i z hlediska jejich naplnění v rámci jednotlivých tematických kategorií, kam článek spadá. Na anglické Wikipedii jsou pak články ohodnoceny celkově podle kvality obsahu, jak je ohodnotili uživatelé (Obrázek 3). 
Obrázek 3. Hodnocení článků na anglické Wikipedii podle kvality - články označené jako FA (featured articles) jsou brány jako nejkvalitnější, kdežto Stuby (pahýly) jako nejméně kvalitní (Přispěvatelé Wikipedie, 2021)

\begin{tabular}{|c|c|c|c|c|c|c|}
\hline \multicolumn{7}{|c|}{ All rated articles by quality and importance } \\
\hline \multirow[b]{2}{*}{ Quality } & \multicolumn{6}{|c|}{ Importance } \\
\hline & Top & High & Mid & Low & ??? & Total \\
\hline$F A$ & 1,366 & 2,166 & 2,104 & 1,465 & 168 & 7,269 \\
\hline $\mathrm{FL}$ & 160 & 598 & 662 & 601 & 103 & 2,124 \\
\hline (A) A & 286 & 598 & 748 & 484 & 88 & 2,204 \\
\hline$\oplus$ GA & 2,646 & 6,057 & 12,115 & 14,460 & 1,716 & 36,994 \\
\hline B & 14,107 & 27,207 & 43,378 & 42,200 & 17,124 & 144,016 \\
\hline C & 13,818 & 42,635 & 101,963 & 176,742 & 66,623 & 401,781 \\
\hline Start & 18,382 & 86,499 & 367,197 & $1,166,358$ & 373,490 & $2,011,926$ \\
\hline Stub & 4,463 & 32,408 & 274,000 & $2,413,178$ & 869,661 & $3,593,710$ \\
\hline List & 4,020 & 14,515 & 44,197 & 137,708 & 76,047 & 276,487 \\
\hline Assessed & 59,248 & 212,683 & 846,364 & $3,953,196$ & $1,405,020$ & $6,476,511$ \\
\hline Unassessed & 120 & 522 & 1,993 & 16,411 & 435,717 & 454,763 \\
\hline Total & 59,368 & 213,205 & 848,357 & $3,969,607$ & $1,840,737$ & $6,931,274$ \\
\hline
\end{tabular}

Kvalita obsahu OER představuje jednu z největších překážek v aplikaci těchto zdrojů do studijních kurikul. Hodnocení kvality v otevřeném prostředí internetu má svá specifika oproti klasickým učebním textům a zavedeným žánrům. Dlouhá a kol. (2015) navrhuje rozpracování kódů, jejichž pomocí se hodnotí jednotlivé kategorie kvality OER, do podoby indikátorů. Stanovit kritéria kvality pro OER je nicméně problematické vzhledem $\mathrm{k}$ tomu, že

$\checkmark$ odborné literatuře nepanuje shoda ani na kritériích kvality pro online zdroje či definici informační kvality (Alkhattabi, Neagu \& Cullen, 2010), posuzování kvality dané informace je individuální a vždy závislé na kontextu a účelu, jemuž tato informace slouží (fitness for use). Proto i posuzování OER a kritéria kvality jsou závislé na tom, pro jakou cílovou skupinu a specifický účel (např. konkrétní diplomovou či seminární práci) je zdroj určen.

Je především rozdíl mezi kritérii kvality, která je možné použít pro dané OER jako celkový systém (tzn. technické prostředí a zpưsob fungování) a mezi kritérii, která hodnotí obsah. Zdroj (ve smyslu úložiště), který naplňuje znaky kvality po stránce technické, může obsahovat i řadu nekvalitních dílčích zdrojů či informací (např. špatně napsané články). V rámci této metodiky se nebudeme zabývat konkrétním obsahem ${ }^{11}$, což by znamenalo provést textovou analýzu konkrétních článků v rámci jednotlivých OER. Tato analýza není ale pro účely našeho výzkumu relevantní. Hodnotila by spíše autory než OER jako systémy, vzhledem

\footnotetext{
${ }^{11}$ Tato kvalita obsahu nepodléhá úplně stejným kritériím jako u zdrojů tištěných, co se týče jejího zajištění (jiný způsob práce redakčního týmu). Při evaluaci spolehlivosti jsou na ni ale kritéria uplatňována stejná.
} 
k tomu, že podoba konkrétního textu je vždy závislá zejména na tom, kdo ho vytváří, a nikoli na obecných principech fungování těchto systémů. Nepomohla by nám tedy ani definovat systémové požadavky, jež je třeba zajistit. Budeme se proto zabývat systémovým prostředím těchto zdrojů spiše specificky, na tomto základě pak můžeme poskytnout konkrétní doporučení pro jejich tvorbu a využívání.

Značná část přístupů v hodnocení kvality OER využívá jakožto kritéria kvality do určité míry komunitu jejich uživatelů, $z$ této komunity tak do jisté míry dělají spolutvưrce těchto zdrojů, a to ve smyslu recenzentů kvality, podle jejichž hodnocení (například formou komentářu či bodového ohodnocení) se mohou orientovat také uživatele další (Clements

a kol., 2015). Pro digitální vzdělávací zdroje podpořené z veřejných rozpočtů jsou vymezeny autorskoprávní požadavky (tedy umístění pod otevřenou licencí) jako jedno z hlavních kritérií kvality (Národní ústav pro vzdělávání, 2016). Jako další důležitý znak kvality pro zdroje, jež je možné využít pro vysokoškolské vzdělávání, můžeme vymezit, zda existuje možnost recenzního řízení (tedy zkontrolování daného článku odborníkem) a zda je tato recenze vyznačena, dále pak uvedení data vytvoření či aktualizace zdroje (Dlouhá a kol., 2015).

Jako základní aspekt v hodnocení kvality obsahu pro akademické využívání je možné definovat tzv. peer review proces. Právě ten je i základem posuzování kvality vědecké práce. Obecně je definován jako hodnocení dané práce experty v oboru. $V$ prostředí vědecké práce je expertíza celkem dobře definována, např. na základě autorství odborných publikací, přičemž se posuzuje jak kvalita časopisů, v nichž jsou práce uveřejňovány, tak jejich percepce vědeckou komunitou (např. četnost citací). Na základě toho se dá celkem jednoduše poznat expertiza autora v daném oboru. U OER je situace jiná: na rozdíl od vědeckých publikací, které jsou úzce specializované, Ize tyto zdroje považovat spíše za učebnice. Jde o zdroje terciární, kritériem kvality je tak právě způsob, jakým se se sekundárními zdroji pracuje.

OER se často věnují komplexním či interdisciplinárním tématům. S rostoucí komplexitou je pak těžké najít experta, který je schopen zhodnotit je jako celek. A zejména u zdrojů, jež jsou zamýšleny pro širokou veřejnost (typu Wikipedie), je navíc těžké určit komu a k jakým vzdělávacím účelům má daný zdroj sloužit. Ten samý článek může být dostačující pro studenta základní či střední školy, ale již ne pro studenta školy vysoké. Pokud OER využívají systém hodnocení kvality, opírají se proto často právě o uživatele, které tak zároveň berou do určité míry jako „peer”, tedy navzájem si rovné (autor a posuzovatel). ${ }^{12}$ Tím posilují prvek své otevřenosti. Uživatelé však nejsou experty v pravém slova smyslu, proto se také nejedná o klasické recenzní řízení srovnatelné s odbornými publikacemi. Jde spíše o

${ }^{12}$ Anglické peer se dá přeložit právě jako „sobě rovný” či „na stejné úrovni”. 
ohodnocení většinou uživatelư, ${ }^{13}$ které nevypovídá o kvalitě daného zdroje obecně, ale pouze o tom, jak kvalitně je vnímán těmi, kdo jej hodnotili. OER pracují se sekundárními zdroji, které by obsahovou kvalitu měly zaručovat. Kvalitní OER se tak do určité míry poznají podle toho, s jak kvalitními sekundárními zdroji pracují, přičemž jde ale také o to, aby poznatky získané z těchto zdrojů nebyly použity mimo pưvodní kontext, případně dezinterpretovány.

\footnotetext{
${ }^{13}$ Například v případě Wikipedie ale již mohou některé diskuze svou náročností připomínat akademické recenzní řizení, vzhledem $\mathrm{k}$ tomu, že mezi uživateli mohou být i odborníci, kteří editují Wikipedii ve svém volném čase.
} 


\section{OER na bázi MediaWiki softwaru}

MediaWiki software je bezplatný open source software, na němž je provozována nejen Wikipedie a jiné projekty nadace Wikimedia Foundation, ale i mnohé další encyklopedie a portály. Byl vytvořen Magnusem Manskem a vylepšen Lee Danielem Crockem. Wikipedie ho začala využívat v roce 2002 a od té doby byl mnohokrát aktualizován a neustále se vyvijí.

MediaWiki software je spolu se svobodnými licencemi Creative Commons páteř́ různých wiki projektů, můžeme ho také označit za jeden z nejčastěji používaných softwarů pro tvorbu OER. Jedním z důvodů jeho rozšiření je právě obliba Wikipedie. Obecnou domněnku, že vysokoškolští studenti největší encyklopedii často využívají, potvrdily i výsledky tematického výzkumu, které ukázaly, že Wikipedie v této cílové skupině hraje primární roli mezi elektronickými zdroji (Dukić \& Strišković, 2015). Výsledky výzkumu, který jsme realizovali v letech 2016-2017 potvrdily, že i čeští vysokoškolští studenti environmentálních oborů preferují pro své studium životního prostředí zejména ty OER, které fungují na bázi MediaWiki softwaru (Obrázek 4). Nejčastěji uvádějí českou verzi Wikipedie, následuje její anglická verze a jako čtvrtý nejpoužívanější zdroj zmiňují Enviwiki, internetovou, internetovou encyklopedii provozovanou Centrem pro otázky životního prostředí Univerzity Karlovy.

Obrázek 4. Graf znázorňující frekvenci využívání OER VŠ studenty environmentálních oborů pro oblast životního prostředí (dle Petiška, 2018a)
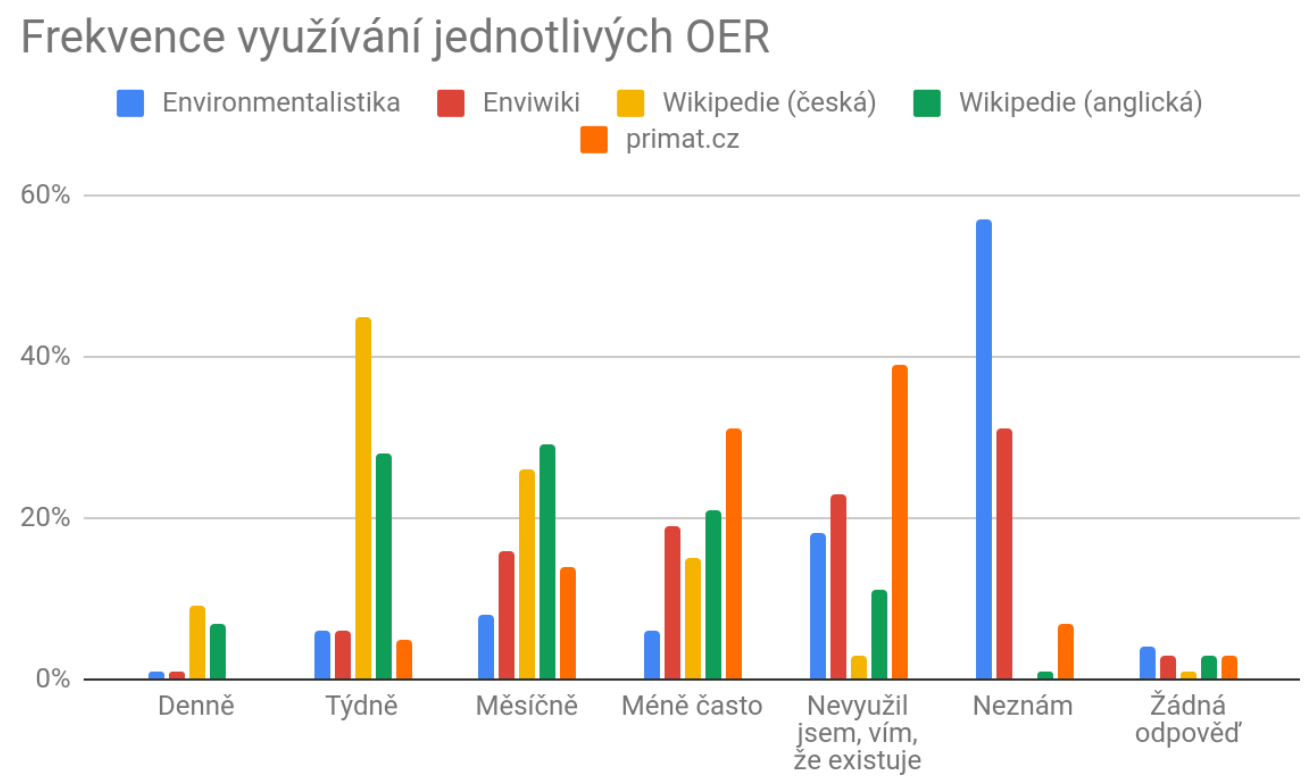
Výzkum realizovaný v roce 2015 (Dlouhá a kol., 2015) poukázal na inovační potenciál OER pro multidisciplinární obory životního prostředí a udržitelného rozvoje. Zároveň podal stručný přehled typů OER, které jsou v ČR k dispozici otevřenou formou pro studium oborů životního prostředí a udržitelného rozvoje, provedl jejich analýzu a navrhl soubor kritérií, podle nichž Ize usuzovat na kvalitu daného zdroje. Výsledky konstatovaly značné přiležitosti pro využívání zvláště $v$ oblasti životního prostředí a udržitelného rozvoje, které souvisí $s$ multidisciplinární povahou těchto oborů. Studie však zároveň upozorňuje na fakt, že tyto možnosti „nebývají naplněny především pro nesnadné rozlišení kvality zdroje v prostředí internetu, ale pravděpodobně i neschopnost samotných studentů takovou kvalitu posuzovat a možná i všeobecnou nedůslednost vysokoškolských učitelů prí prosazování etických norem při studiu." Z výsledků výzkumu je patrné, že mezi zdroji, které nejlépe naplňují vytyčená kritéria, se umístily právě zdroje zařazené do kategorie „prostředí otevřené pro úpravy”, které fungují na bázi MediaWiki softwaru (Tabulka 5).

Tabulka 5. Výsledek expertního hodnocení/kódování (tým výzkumníků zabývajících se OER) vybraných OER zdrojů podle kritérií kvality. „Hodnoty“ kódů (ANO, NE, 0) představují jejich zjednodušený kvalitativní popis: ANO znamená, že dané kritérium bylo víceméně naplněno, NE pak značí opak (většinou dané kritérium naplněno nebylo). „Hodnota“ 0 byla užita v prípadech, že nebylo možné z různých důvodů prǐřadit zdroji předchozí dvě „hodnoty“ (Dlouhá a kol., 2015).

\begin{tabular}{|c|c|c|c|c|c|c|c|c|c|c|}
\hline \multicolumn{2}{|c|}{ Kategorie / Kódy } & název zdroje & $\begin{array}{l}\text { copy- } \\
\text { right }\end{array}$ & $\begin{array}{c}\text { autor- } \\
\text { stvi }\end{array}$ & $\begin{array}{l}\text { datum } \\
\text { publik. }\end{array}$ & $\begin{array}{l}\text { řádné } \\
\text { citace }\end{array}$ & recenze & $\begin{array}{c}\text { vyzna- } \\
\text { čení kva- } \\
\text { lity }\end{array}$ & $\begin{array}{c}\text { korektni } \\
\text { po- } \\
\text { stup*** }\end{array}$ & $\begin{array}{c}\text { "nabídka“ pro VŠ výuku a rozvíjené kompetence } \\
\text { z hlediska EV a VUR }\end{array}$ \\
\hline \multirow{3}{*}{\multicolumn{2}{|c|}{$\begin{array}{l}\text { částečně uzavřené } \\
\text { prostředi (všechny či } \\
\text { některé funkce jen } \\
\text { pro přihlášené, nebo } \\
\text { otevřené omylem) }\end{array}$}} & $\frac{\text { Informačni systém }}{\underline{M U}}$ & $\mathrm{NE}$ & 0 & ANO & 0 & $\mathrm{NE}$ & NE & ANO & Snadná dostupnost - materiály z oblasti ekologie a Žp \\
\hline & & $\frac{\underline{\text { Studiiní opory VŠB- }}}{\underline{\underline{T U}}}$ & ANO & 0 & 0 & 0 & 0 & 0 & 0 & $\begin{array}{l}\text { Snadná dostupnost - materiály katedry ochrany ŽP v } \\
\text { prủmyslu }\end{array}$ \\
\hline & & Khanova škola & $\mathrm{NE}$ & 0 & ANO & 0 & ANO & NE & ANO & $\begin{array}{l}\text { Atraktivní videa - pro rychlokurz základů biologie a eko- } \\
\text { logie }\end{array}$ \\
\hline \multirow{3}{*}{\multicolumn{2}{|c|}{$\begin{array}{l}\text { prostředi otevřené } \\
\text { pro čteni }\end{array}$}} & Environmentalistika & ANO & $\mathrm{NE}$ & NE & NE & NE & NE & 0 & $\begin{array}{l}\text { Všechny piliře udržitelnosti v globálním i lokálnim po- } \\
\text { hledu - stručnost, přehlednost, utříděná témata }\end{array}$ \\
\hline & & $\frac{\text { Studovna Elportálu }}{\underline{\text { MUNI }}}$ & ANO & ANO & ANO & 0 & 0 & ANO & ANO & $\begin{array}{c}\text { Fulltextové učebnice - vysoká kvalita, dostupnost, spo- } \\
\text { lehlivost, oborové členěni (mimo ŽP a UR) }\end{array}$ \\
\hline & & $\frac{\text { Portál pro cestovni }}{\underline{\text { ruch UHK }}}$ & 0 & 0 & ANO & 0 & $\mathrm{NE}$ & NE & 0 & $\begin{array}{c}\text { Úložiště materiálủ - různorodost (obsah, forma), kolisa- } \\
\text { jící kvalita, často mimo ŽP a UR }\end{array}$ \\
\hline \multirow{3}{*}{$\begin{array}{l}\text { otevrené } \\
\text { interak- } \\
\text { tivni* }^{*}\end{array}$} & $\begin{array}{c}\text { testy a } \\
\text { kvizy }\end{array}$ & Prírodné javy & ANO & 0 & 0 & 0 & ANO & 0 & 0 & $\begin{array}{c}\text { Interaktivni portál, přehlednost, testováni znalostí (pří- } \\
\text { prava na zkoušky) }\end{array}$ \\
\hline & \multirow{2}{*}{$\begin{array}{c}\text { dis- } \\
\text { kusni } \\
\text { prostor } \\
* * *\end{array}$} & $\underline{\text { INFO lu2 }}$ & ANO & 0 & $\mathrm{NE}$ & 0 & $\mathrm{NE}$ & NE & NE & 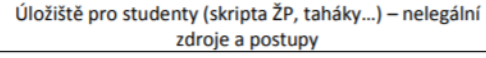 \\
\hline & & Technika na ČZU & $\mathrm{NE}$ & 0 & ANO & 0 & $\mathrm{NE}$ & NE & $\mathrm{NE}$ & $\begin{array}{l}\text { Zdroje pro studenty oboru - spravuje absolvent, využiva } \\
\text { k šî́̃eni reklam }\end{array}$ \\
\hline \multirow{3}{*}{\multicolumn{2}{|c|}{$\begin{array}{l}\text { prostředí otevřené } \\
\text { pro úpravy }\end{array}$}} & Enviwiki & ANO & ANO & ANO & 0 & 0 & 0 & 0 & $\begin{array}{l}\text { Multidisciplinární povaha textů umožňuje skloubit po- } \\
\text { znatky z rúzných oblasti ŽP a UR a propojit aktéry a zna- } \\
\text { losti (použivání hyperlinkủ, kategorie, atd). }\end{array}$ \\
\hline & & Wikiskripta & ANO & ANO & ANO & ANO & ANO & ANO & ANO & $\begin{array}{l}\text { Exemplárni př́iklad dělby práce ve Wiki - zapojeni + kva- } \\
\text { lita (jen několik článkủ (týkajících se ŽP a zdravi) }\end{array}$ \\
\hline & & Wikipedie & ANO & ANO & ANO & ANO & ANO & 0 & 0 & $\begin{array}{l}\text { Mezioborové propojeni témat, zdúrazněni souvislostí, } \\
\text { možnost propagace témat (odkazy z jiných stránek) }\end{array}$ \\
\hline \multirow{3}{*}{\multicolumn{2}{|c|}{$\begin{array}{l}\text { primárně komerčni } \\
\text { stránky (mira otevře- } \\
\text { nosti nehraje roli) }\end{array}$}} & primat.cz & ANO & 0 & ANO & 0 & $\mathrm{NE}$ & NE & NE & $\begin{array}{l}\text { Materiály nelegální (otázky ke zkoušce atd.), rủzná kva- } \\
\text { lita, komerčni cil }\end{array}$ \\
\hline & & veiska.cz & ANO & 0 & ANO & 0 & $\mathrm{NE}$ & NE & $\mathrm{NE}$ & $\begin{array}{c}\text { Materiály pro všechny VŠ - nekorektni sdileni (otázky } \\
\text { k testủm atd.) }\end{array}$ \\
\hline & & $\underline{\text { Unium }}$ & ANO & ANO & ANO & 0 & NE & NE & NE & $\begin{array}{c}\text { Materiály pro všechny VŠ - nekorektni sdilení (nabídka } \\
\text { vypracováni praci) }\end{array}$ \\
\hline
\end{tabular}

* neumožňujicí úpravy existujicích textů $\mid{ }^{* *}$ možnost přidávat materiály $\quad{ }^{* * *}$ Užití zdroje nevede k plagiátorství; práci s nekvalitními zdroji; nekritickému přistupu,...

Na základě výše uvedeného je patrné, že otevřené vzdělávací zdroje fungující na bázi MediaWiki softwaru jednak často naplňují základní podstatu těchto zdrojů, protože většinou 
fungují pod otevřenou licencí (ta poskytuje možnost nejen využívání, ale i sdílení a modifikace), ale vzhledem ke specifickému prostředí, které poskytují, jsou i uživatelsky přívětivé, a proto často značně využívané. Nejznámějším příkladem těchto zdrojů je Wikipedie, jejiž principy fungování částečně přejímají také ostatní projekty založené na MediaWiki softwaru, označované též jako wikisystémy či wiki (Tabulka 6).

Tabulka 6. Základní principy projektů hnutí Wikimedia, které představují nejvýznamnější zdroje fungující na bázi MediaWiki softwaru (dle Přispěvatelé Wikipedie, 2018)

Nezaujatý úhel pohledu jako povinný editorský princip.

Možnost téměř každého uživatele editovat články (většinu) bez registrace.

„Wikiproces" jako finální rozhodovací mechanismus všeho obsahu.

Vytvoření vstřícného a kolegiálního editorského prostředí.

Copyleftové licence obsahu; v praxi podle projektu bud' public domain, GFDL nebo CC-BY-SA, nebo CC-BY.

Zachovávání míst pro diskuze, což napomáhá řešení obzvlášt' závažných problémů. Na anglické Wikipedii má arbitrážní výbor pravomoc nařizovat určitá závazná, pravomocná rozhodnutí - jako například zablokování uživatele. 


\section{Ekonomické aspekty využívání a vytváření OER}

Otevřené vzdělávací zdroje jsou podstatně levnější eventualitou vzdělávacích materiálů a studentům mohou ušetřit značné finanční prostředky (Hilton, 2016). Právě v USA, kde ceny učebnic představují pro studenty značnou zátěž, dochází v současné době $k$ velkému posunu $v$ oblasti OER. Různé iniciativy, které jsou podporovány americkými nadacemi, vytváří kvalitní volně dostupné vzdělávací zdroje. Jedním z nejznámějších příkladů je Iniciativa OpenStax vzniklá v roce 2012 při Rice University, jejiž učebnice jsou používány již na více než polovině amerických vysokých škol a kromě toho i na řadě dalších po celém světě (včetně Univerzity Karlovy). Odhaduje se, že jejich využívání již studentům ušetřilo celkem přes 800 milionů dolarů. ${ }^{14}$ Přitom právě tato revoluce ve vzdělávacíchp materiálech může být také jedním z důvodů, proč se částky, které studenti v USA platí za učebnice, snižují již pět let po sobě, přičemž jen za rok 2018-2019 došlo k poklesu o 21 \% oproti minulému roku (viz Tabulka 7). V českém prostředí studie na toto téma neexistují, ale podle zahraničních zdrojů se jen na Univerzitě Karlově odhadují kumulativní úspory díky studiu z těchto otevřených učebnic na více než 3 miliony korun. ${ }^{15}$

Tabulka 7. Pokles průměrných studentských výdajů za studijní materiály v USA (průměrná cena za jednoho studenta). (AAP, 2019) ${ }^{16}$

\begin{tabular}{|l|l|}
\hline Akademický rok & Výdaje za studijní materiály \\
\hline $2014-2015$ & 691 USD \\
\hline $2015-2016$ & 607 USD \\
\hline $2016-2017$ & 543 USD \\
\hline $2017-2018$ & 507 USD \\
\hline $2018-2019$ & 492 USD \\
\hline
\end{tabular}

\footnotetext{
${ }^{14}$ https://openstax.org/impact

15 https://openstax.org/separatemap

${ }^{16} \mathrm{https://publishers.org/news/new-data-shows-continued-decline-in-student-spending-on-college-}$ course-materials/
} 
Úspory jsou zvláště patrné v př́padě OER MWS, které mohou těžit z toho, že se do jejich vytváření leckde zapojuje široká veřejnost bez nároku na honorář. Výzkumníci zároveň uvádí, že diseminace poznatků například prostřednictvím Wikipedie je 2000krát cenově výhodnější než prostřednictvím tradičních diseminačních technik, a argumentují pro její podporu z veřejných prostředků; navrhují například, že editace tematického článku na Wikipedii o odborné poznatky výzkumu by mohla být zohledněna $v$ návrzích projektů do grantových soutěží (Thompson \& Hanley, 2018). Zavedením OER MWS je tak možné ušetřit značné finanční prostředky oproti tradičním publikačním modelům, jako jsou vysokoškolská skripta. Výše těchto úspor závisí zejména na rozsahu jejich implementace a na řadě dalších faktorů, jako je např́iklad dobrovolnost tvůrců obsahu. Vzhledem k tomu, že komunita OER MWS funguje nejlépe na principu vnitřní motivace (viz část Komunita), je možné ušetřit i za autorské honoráře. Nejvýznamnější nákladovou položku tak tvoří technická stránka věci (zaplacení administrátora, popř. manažera projektu, který se podílí na organizaci tvorby obsahu). Pro ilustraci možných procentuálních úspor viz Tabulka 8.

Prakticky jediný náklad, který při tvorbě OER zůstává, je funkce „vydavatele”, v případě OER právě již zmíněné náklady na technické zajištění projektu a jeho organizaci. Důležité ale je, že odpadají transakční náklady jak na jejich výrobu (hlavně náklady na tiskárnu), tak zejména distribuci. Studenti mohou vytvářet obsah například v rámci kurzů pod vedením pedagoga. ${ }^{17}$ Otázkou tedy pouze je, jak vyřešit „vydavatelské” náklady OER MWS. Možným řešením je institucionální podpora (jako příklad dobré praxe můžeme uvést lékařská WikiSkripta). Vytvoření OER MWS je včetně odměny za IT specialistu možné pořídit v řádech tisíců či nižších desítek tisíc korun. Podobná odměna se může vyplácet také administrátorovi projektu. Úspory na straně uživatelů (studentů) pak mohou představovat každoročně řádově statisíce korun. Konkrétní částky samozřejmě záleží na velikosti projektu a množství jeho uživatelů.

\footnotetext{
${ }^{17}$ Př́kladem dobré praxe je např́íklad zapojení studentů do tvorby Enviwiki: https://www.enviwiki.cz/wiki/Kategorie:Sport a \%C5\%BEivotn\%C3\%AD prost $\%$ C5\%99ed\%C3\%AD
} 
Tabulka 8. Příklad možných procentuálních úspor při tvorbě OER MWS oproti klasickým mediálním formátům

\begin{tabular}{|l|l|l|l|}
\hline & Tištěná skripta & $\begin{array}{l}\text { Elektronická } \\
\text { skripta }\end{array}$ & OER MWS \\
\hline Distributor & $40 \%$ & $40 \%$ & - \\
\hline Tiskárna & $30 \%$ & - & - \\
\hline Autor & $8 \%$ & $8 \%$ & -18 \\
\hline Vydavatel & $12 \%$ & $12 \%$ & $12 \%$ \\
\hline DPH & $10 \%$ & $10 \%$ & - \\
\hline
\end{tabular}

${ }^{18}$ I autora je možné zaplatit, ukazuje se ale, že v př́padě OER WMS funguje autorský kolektiv nejlépe na bázi vnitřní či jiné nefinanční motivace (například studenti si sami vytváří materiály na zkoušky). 


\section{Benefity a zápory OER MWS}

Otevřené vzdělávací zdroje na bázi Mediawiki softwaru přináší řadu benefitů, ale také potencionálních záporů - jako nejvýznamnější můžeme uvést následující:

\section{Benefity}

- Úspora prostředků - Studijní materiály, které jsou online, mohou vést $k$ úspoře prostředků jak na straně instituce, ${ }^{19}$ tak na straně studentů.

- Snadná aktualizace - V současném rychle se měnícím světě poznatky rychle zastarávají, proto jsou potřeba časté aktualizace. Zdroje na bázi MWS jsou k tomu ideální.

- Snadná úprava pro specifické účely - Učitel může učebnici upravit (zkrátit, doplnit či jinak modifikovat) pro účely svého kurzu.

- Vyšší efektivita - Prostřednictvím hyperlinků a odkazů se může student dostat k poznatkům, které ho zajímají a přesahují rámec studijní látky (mnohem snadněji než v klasickém printu). Je také možné předpokládat, že specifika prostředí OER pomáhají studentovi lépe chápat souvislosti a vidět problematiku v kontextu. Rovněž může pomoci $\mathrm{k}$ interdisciplinárnímu myšlení, stejně jako k rozvoji aktivního učení (tzv. inquiry-based learning).

- Změna média - Dnešní studenti vyrůstají ve světě, kde tráví již od dětství více času s digitálními platformami než s klasickými knihami. Klasický učební text pro ně může být méně pritažlivý. Na prostředí wiki si zvykají od útlého věku.

- Snížení zátěže životního prostředí - S rostoucími požadavky na modifikaci obsahu rostou také náklady na jeho recyklaci. Celý životní cyklus učebnic (papír, tisk, logistika, prodej) představuje environmentální zátěž. Osobní počítač (tablet), ač taky představuje určitou zátěž, se stává nezbytností života v současné době. Pokud ho tedy studenti už mají, mohou omezit využívání tištěných zdrojů.

- Přispívání ke znalostní společnosti - OER MWS podporují proces celoživotního vzdělávání vzhledem k vytváření prostoru pro širokou participaci.

\section{Zápory}

- Snadná modifikace obsahu - Text může často měnit kdokoliv a kdykoliv, to se může negativně odrazit na jeho kvalitě. Pokud si např́klad pedagog přečte text na zdroji a

\footnotetext{
${ }^{19}$ Za předpokladu, že instituce vytváření studijních materiálů dotuje. Pokud jí tvorba studijních materiálů přináší naopak zisk (studenti si je kupují), je možné snízit transakční náklady a nabízet materiály v e-formě za určitý poplatek (pak se ale nejedná o klasické OER).
} 
pak na něj odkáže studenty, může se text během této chvíle změnit bez pedagogova vědomí (dá se ale vyřešit tím, že odkáže na specifickou verzi stránky, z níž čerpal).

- Problém se zajištěním garance kvality - Změny by měl někdo pravidelně kontrolovat, což je časově náročné.

- Problém s autorstvím - Má být pod textem uveden autor, když jej pak mohou anonymní editoři výrazně změnit bez jeho vědomí?

\section{Specifický žánr textu}

Obsah, jenž je předkládán prostřednictvím OER na bázi Mediawiki softwaru, je někdy možné chápat také jako specifický žánr textu. Výsledný text je dynamický a proměnlivý, můžeme hovořit o možnosti třetí dimenze (3D) čtení, vzhledem k tomu, že neumožňuje pouze klasické lineární čtení textu, ale také průběžné „proklikávání” a „přeskakování” na související témata. To je možné zejména díky prostředí hypertextu, tedy hyperlinkovým odkazům a přesměrování na různá spojení.

Ačkoliv technologie hypertextu vznikala s rozvojem počítačů až ve druhé polovině dvacátého století, myšlenka přesměrování textu na jeho jiné relevantní části je starší. $S$ touto inovací přišel Ephraim Chambers, který publikoval svoji dvousvazkovou Cyclopædii či univerzální slovník umění a věd v roce 1728. A právě Cyclopædie, která obsahuje široký rozsah zpracovaných témat, předkládá inovaci spočívající v umístění křižových odkazů na jiné sekce $v$ článcích. Tím se inspirovali také francouzští encyklopedisté. Hlavní redaktor encyklopedie Denis Diderot viděl ideální encyklopedii jako index spojení, ${ }^{20}$ nejde tedy pouze o popsání jednotlivých témat, ale také o vztah mezi nimi (pomocí křížového odkazování). Encyklopedisté tudíz usilovali zejména o to, aby si čtenáři uvědomili souvislosti, ${ }^{21}$ pro což se dnes používá pojem interdisciplinární či transdisciplinární myšlení. Moderní technologie jako OER MWS pak myšlenku křížového odkazování inovovaly právě do formy hypertextu.

Další aspekt, který je spojen s tvorbou OER na bázi Mediawiki softwaru a jenž z něj činí do určité míry „nový žánr”, je kolaborativní proces vytváření textu a snadnost zdrojování tvrzení (pomocí hyperlinku se dá jednoduše rozkliknout citovaný text). Kolaborativní proces vytváření článků svým rozsahem a významem přesahuje klasický editační proces textů. To

\footnotetext{
${ }^{20} \mathrm{https}$ ://en.wikipedia.org/wiki/History of encyclopedias. Popsat tyto vztahy je v klasické encyklopedii značně obtižné, $v$ tom také spočívá jedna z hlavních výhod Wikipedie, která právě díky hyperlinkům a odkazům umožňuje lépe chápat souvislosti.

${ }^{21} \mathrm{https}$ ://en.wikipedia.org/wiki/History of encyclopedias .

To je nicméně v tištěných encyklopediích problematické a spočívá v tom také hlavní výhoda digitálních projektů, jako jsou OEW MWS. Můžeme proto konstatovat, že projekty jako Wikipedie navazují na myšlenky encyklopedistů. Francouzská Encyklopedie stála u zrodu proměn sociální reality (nejen Velké francouzské revoluce, ale i co se týče změny myšlení a nástupu pozitivismu). OER MWS projekty možná také podněcují určitou intelektuální změnu (například rozvoj svobodného sdílení otevřeného obsahu).
} 
souvisí s podobou článků, které často nepředstavují pouhé stručné vymezení problému, jak tomu bývá zvykem u klasických encyklopedií. Některé bývají značně rozsáhlé a svým obsahem a detailním zpracováním připomínaji již spíše odbornou publikaci či sekci úvod (introduction) ve vědeckých článcích než běžný encyklopedický článek. Úvod v některých heslech pak připomíná abstrakt vědeckého článku, který shrnuje celou jeho problematiku.

Vzhledem k tomu, že finální text nemá žádného konečného „garanta kvality”, editora ani redaktora, zůstává do jisté míry stále v procesu vytváření. To často může mít za následek jistou nepřehlednost až chaotičnost textu, jež se projevuje např́ílad $v$ nesourodosti jednotlivých vět $v$ rámci celkového kontextu, což ztěžuje jeho četbu. Na druhou stranu se tím, že odpadá garant kvality finálního textu, zvyšuje tlak na kvalitu jednotlivých částí. To je vidět zejména u Wikipedie, kde se často vedou dlouhé spory třeba jen o jedno tvrzení a jeho ověřitelnost respektovanými zdroji. Ukazuje se, že články vnímané komunitou Wikipedie jako nejkvalitnější, jsou také nejlépe ozdrojované (viz Tabulka 9 a Obrázek 5). Tyto články pak často nepůsobí jako souvislý text, ale spíše jako seznam jednotlivých tvrzení. Wikipedii můžeme proto často chápat možná spíše jako vyhledávač důležitých poznatků a zdrojů o různých tématech než jako encyklopedii s rigidně stanovenými pravidly, která garantují vnitřně koherentní text. 
Tabulka 9. Medián počtu editací, editorů, slov, referencí a poměru počtu slov na počet referencí u environmentálních článků na anglické Wikipedii ilustruje, že nejkvalitnější články (dle hodnocení komunity Wikipedie) se signifikantně liší od těch méně kvalitních ve všech těchto ohledech. Počet analyzovaných článků: 7048 (Petiška a kol., v publikačním procesu)

\begin{tabular}{|c|c|c|c|c|c|c|}
\hline $\begin{array}{l}\text { Kategorie } \\
\text { kvality }\end{array}$ & $\begin{array}{l}\text { Počet } \\
\text { článků }\end{array}$ & $\begin{array}{l}\text { Počet editací } \\
\text { provedených } \\
\text { v článku } \\
\text { (medián) }\end{array}$ & $\begin{array}{l}\text { Počet } \\
\text { editorů } \\
\text { článku } \\
\text { (medián) }\end{array}$ & $\begin{array}{l}\text { Počet slov } \\
\text { v článku } \\
\text { (medián) }\end{array}$ & \begin{tabular}{|l} 
Počet \\
referencí \\
uvedených v \\
článku \\
(medián)
\end{tabular} & $\begin{array}{l}\text { Poměr počtu } \\
\text { slov/referen } \\
\text { cí v článku } \\
\text { (medián) }\end{array}$ \\
\hline $\begin{array}{l}\text { Kategorie } \\
\text { nejvyšší kvality } \\
\text { (Trí́da Nejlepší } \\
\text { články + Tř́́da } \\
\text { Dobré články) }\end{array}$ & 94 & 513 & 148 & 4317 & 120 & 33 \\
\hline $\begin{array}{l}\text { Kategorie } \\
\text { střední kvality } \\
\text { (Tř́ida B + Třída } \\
\text { C) }\end{array}$ & 1594 & 295 & 123 & 2124 & 48 & 41 \\
\hline $\begin{array}{l}\text { Kategorie } \\
\text { nejnižší kvality } \\
\text { (Tř́ída Start + } \\
\text { Třída Pahýl) }\end{array}$ & 5360 & 51 & 26 & 357 & 7 & 47 \\
\hline
\end{tabular}

Obrázek 5. Poměr počtu slov na počet referencí v environmentálních článcích na anglické Wikipedii. Modrá barva je použita pro články vnímané komunitou Wikipedie jako nejkvalitnější, červená pro články vnímané jako středně kvalitní a zelená pro články vnímané komunitou jako nejméně kvalitní. Svislá osa značí počet referencí, vodorovná osa počet slov. Počet analyzovaných článků: 7048 (Petiška a kol., v publikačním procesu)

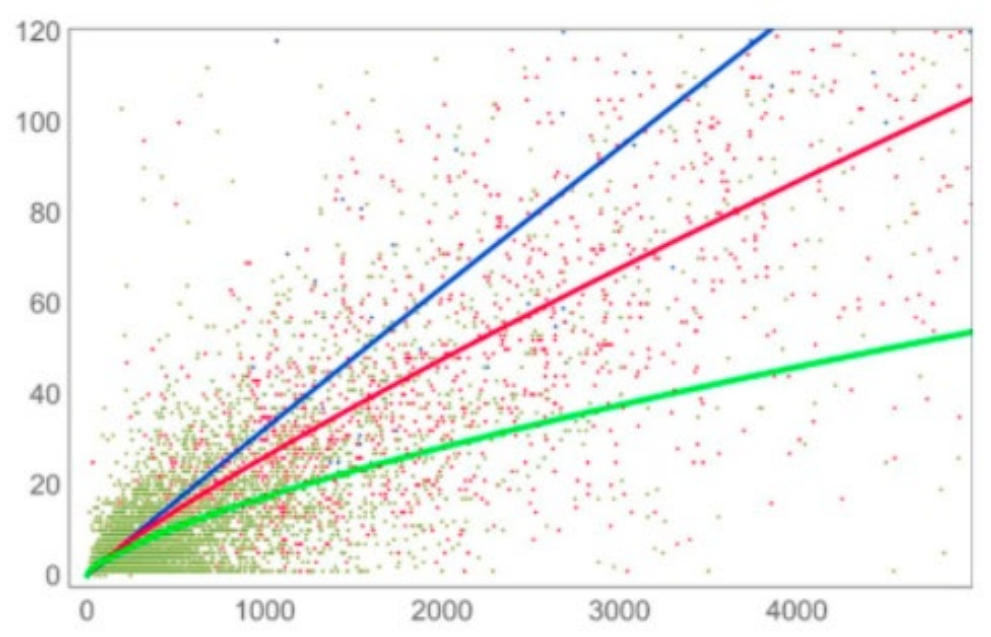




\section{Wikipedie v kontextu zdrojů pro VŠ vzdělávání}

Vznik internetových zdrojů přinesl značnou změnu do oblasti vzdělávacích zdrojů použitelných pro vysokoškolské vzdělávání. Vzhledem k tomu, že internetové zdroje nabízí pestrou škálu rozličných materiálů různé kvality, nemusí být snadné se v nich orientovat. Studenti by tedy měli být vedeni $k$ tomu, jak se zdroji pracovat a podle jakých kritérií si vybírat nejen texty ke studiu (které často doporučuje pedagog), ale zejména pro psaní různých seminárních a závěrečných prací. Tak aby byli schopni rozpoznat vědecké studie a primární prameny od těch sekundárních či terciárních, jako jsou právě různé wiki. Tyto kompetence si mohou dobře osvojit, pokud jsou sami vedeni $k$ vytváření učebních textů (jako např́íklad $v$ př́padě WikiSkript).

Oproti jiným zdrojům na bázi MediaWiki softwaru, které jsou leckdy částečně přijímány jako doplněk oficiálních vzdělávacích materiálů a $v$ rámci vysokoškolského vzdělávání respektovány (například již výše zmiňovaná Wikiskripta či Wikisofia), zaujímá Wikipedie v rámci vzdělávacího procesu poněkud diskutabilní pozici a na její kvalitě a vhodnosti využívání v akademickém prostředí není shoda. I přes jisté indicie, že ji používají nejen studenti, ale i akademici (Thompson \& Hanley, 2018), je na ni ve vysokoškolském prostředí stále často nahliženo s jistou nedůvěrou (Jemielniak, 2019). To je nicméně pochopitelné vzhledem $\mathrm{k}$ tomu, že její kvalita značně variuje a nemá žádného oficiálního garanta kvality, který by odpovídal za finální podobu textu.

Wikipedie nicméně může posloužit jako inspirace jiným wiki projektům i v oblasti vysokoškolského vzdělávání, jak se ostatně v českém prostředí již často děje, a komunity těchto zdrojů také spolupracují a vyměňují si dobrou praxi. A přestože Wikipedie není v oblasti vysokoškolského vzdělávání respektovaným zdrojem, nastavuje vysoké standardy v oblasti aktuálnosti (viz kapitola Aktuálnost). To platí zejména v její anglické verzi, kde jsou články často doplňovány i nejnovějšími vědeckými výsledky (jak tomu bylo například $v$ prípadě covidové pandemie). Wikipedie má značně propracovaný systém na řešení sporů, který může sloužit také pro inspiraci. Na diskuzních stránkách článků umožňuje diskuzi odborníků s různými názory na konkrétní témata. To slouží k nalézání konsensu i v oblasti vědeckých pojmů, jejichž deskripce a explanace je problematická. 


\section{Využívání OER MWS}

Při využívání OER MWS je vhodné si položit následující otázky: „Co od zdroje očekáváme, k jakým informačním potřebám ho zamýšlíme využít?” a „K čemu slouží daný zdroj, který chceme využit?" Právě díky uvědomění si našich potřeb a specifik zdroje, o jehož využití se rozhodujeme, můžeme najít nejvhodnější OER MWS pro naše potřeby s ohledem na požadovanou kvalitu (například vysokoškolák by při studiu na zkoušky neměl využívat takové zdroje, jež jsou primárně designované pro nižší stupně vzdělávání).

\section{Účely využívání}

Otevřené vzdělávací zdroje na bázi MediaWiki softwaru nabízí příležitosti pro široké spektrum využívání na všech úrovních vzdělávání. Největší benefity a možnosti aplikace představuje však vzdělávání celoživotní a vysokoškolské. V rámci vysokoškolského vzdělávání se pak OER MWS hodí zejména pro studia, jež vyžadují transdisciplinární přesah a prístup k nejnovějším poznatkům. Tyto zdroje plní svůj účel zejména v oblastech, kde je kladen důraz na:

- Otevřenost poznatků - Otevřenost poznatků je základním požadavkem pro účinnou diseminaci znalostí.

- Potřebu aktuálních informací - Znalosti se rychle vyvijí. Zejména v oblasti vysokoškolského vzdělávání je proto třeba pracovat s aktuálními zdroji, které jsou často $\mathrm{k}$ dispozici dříve ve verzi online než v podobě tištěné. OER umožňují snadné zakomponování odkazu na tematické zdroje.

- Interdisciplinární myšlení - V rámci vysokoškolského vzdělání je oceňováno přemýšlení v souvislostech. Prostředí OER umožňuje snadné přesměrování na související témata a přehlednou strukturu pro pochopení souvislostí.

- Propojení aktérů - Různé problematiky studia požadují propojení různých aktérů při tvorbě poznatků a řešení problémů. Otevřené vzdělávací zdroje mohou například vytvářet odborníci z akademické sféry, avšak umožňují také zapojení aktérů z praxe, kteří mohou doplnit zdroj o aktuální poznatky ze své každodenní činnosti.

Dále je třeba konkrétně zmínit pro jaké specifické účely studia se OER na bázi MediaWiki softwaru hodí nejvíce. Samozřejmě záleží na povaze každého zdroje, která může být designována pro různé účely. Přesto je možné definovat, pro jaké účely jsou tyto zdroje ideální, aby se v plné míře mohla projevit jejich přidaná hodnota oproti klasickým zdrojům, jakými jsou tištěná skripta či webové stránky.

Jako hlavní principy OER na bázi MWS, jež je odlišují od ostatních zdrojů, můžeme vymezit zejména možnost jejich široce otevřené kolaborativní editace, tedy možnost, že daný 
zdroj po jeho vytvoření může editovat kdokoliv, ne pouze jeho tvưrci či jimi schválení uživatelé. Právě to ale může představovat dvojsečnou zbraň. Na jedné straně zdroj může upravovat a aktualizovat nejnovějšími poznatky kdokoliv s přístupem k internetu, což podporuje principy občanské vědy (citizen science) a demokratizaci tvorby poznatků. Na druhé straně právě anonymní editace může představovat vážný problém pro finální podobu textu, nebot' anonymní přispěvatel může záměrně či neúmyslně zdroji škodit, přidávat nevhodné příspěvky či mazat existující části, a tak snižovat jeho kvalitu.

$\checkmark$ prípadě, že zůstane zachována anonymní možnost editace - jako hlavní deviza OER MWS - je potřeba o to více řešit způsoby zajištění jeho kvality a účely využívání.

V př́padě anonymního OER MWS je totiž problematické, aby studenti považovali tyto zdroje za stejně seriózní jako např. vysokoškolská skripta a jiné učebnice psané profesionálem v oboru či autorským kolektivem. Naopak by při jejich využívání měli být značně obezřetní.

Jako ideální účel využívání OER MWS se v prrípadě jejich anonymity pak nabízí rozcestník $\mathrm{k}$ dalším zdrojům. Tyto zdroje by tedy neměly sloužit jako koherentní celek, který nahrazuje klasické zdroje, ale spíše jako úvod do problematiky, jakási „brána do světa znalosti”, tedy spíše vyhledávač informací a zdrojů o studované problematice než klasický učební text.

Naopak jejich využívání při studiu na zkoušky ve smyslu náhrady oficiálního vysokoškolského zdroje se doporučit většinou nedá; výjimku tvoří případy, kdy by daný zdroj pedagog sám zhodnotil a doporučil. Ale i v tomto případě je třeba být obezřetný, protože zdroj se od schválení odborníkem může změnit. Studenti by proto měli být upozorněni, která verze stránky ${ }^{22}$ prošla kontrolou, a studovat $z$ této verze.

\footnotetext{
${ }^{22}$ Lepší je citovat číslo stránky než čas príistupu (či v ideálním př́ípadě obojí). OEW MWS totiž umožňují provést více než jednu editaci v rámci jedné minuty.
} 


\section{Využitelnost}

Pokud se rozhodujeme, zda, popř. jaký otevřený vzdělávací zdroj na bázi Mediawiki softwaru využít, hraje ústřední úlohu uvědomění si naší vzdělávací/informační potřeby; je třeba zodpovědět otázku: „K čemu plánujeme daný OER MWS využít?"

Správně vytvářený OER MWS má totiž definovanou cílovou skupinu, jejíž informační a vzdělávací potřeby by měl být schopen uspokojit. Je rozdíl například mezi používáním jednotlivých wiki systémů. Kupříkladu Wikipedie má cílovou skupinu značně otevřenou (definuje se primárně jako encyklopedie) a tvorba jejího obsahu je liberální v tom smyslu, že záleží na komunitě každého článku, jak si jej utvoří k obrazu svému. Naproti tomu např́íklad česká medicínská WikiSkripta se zaměřují na studenty lékařských oborů a jejich ambicí je studenty vzdělávat v těchto oborech, přičemž není cílem nahradit klasická skripta či učebnice, ale sloužit jako jejich doplněk. Encyklopedie životního prostředí Enviwiki je zase určena zájemcům o poznatky z oblasti životního prostředí, at' již studentům či laikům, a jejím účelem není nahradit Wikipedii, od které se $v$ řadě ohledů odlišuje.

Obecně vzato Ize anonymní OER MWS pouze těžko doporučit jako primární zdroj ke studiu dané problematiky např́ílad v prrípadě vysokoškolského vzdělávání, tady by studenti měli být vedeni hlavně k využívání tradičních respektovaných zdrojů (viz část Účely využívání). I anonymní zdroj je ale možné vhodně využít, a to zejména jako rozcestník k dalším zdrojům, jejichž rešerši může předkládat například $v$ referencích na konci článku či v sekci typu literatura pro dalši studium. Pokud zdroj nechceme využít pouze pro svou vzdělávací potřebu, ale třeba na jeho základě vytvářet jiný zdroj, je nutné se nejprve podívat na licenční podmínky, t.j. pod kterou licencí je námi využívaný zdroj licencován a zda tato licence umožňuje další využití. Ideální je, pokud jde o nějakou formu otevřené licence.

\section{Ověřitelnost}

Ověřitelnost tvrzení respektovanými zdroji je základním kritériem pro orientaci $v$ otevřených vzdělávacích zdrojích - zejména anonymních - na bázi MediaWiki softwaru.

Díky ověritelnosti jednotlivých tvrzení se zároveň do určité míry z anonymního zdroje stává také zdroj neanonymní - co se týče ozdrojovaných informací v něm obsažených. $\mathrm{Na}$ vysokých školách jsou studenti například často vedeni k tomu, že by neměli citovat Wikipedii. To by ale správně nemělo být vůbec třeba. V př́ipadě, že články jsou na Wikipedii dobře napsány (podle jejích pravidel), každé tvrzení, jež není veřejně známé a triviální (a mohlo by tedy být využitelné pro VŠ účely) by mělo být řádně ozdrojováno. Uživatel by tak správně měl citovat nikoli Wikipedii, ale odkazovaný zdroj. 
Pokud se nám ale líbí například nějaká formulace v článku na Wikipedii, jež není ráaně ozdrojována, můžeme se přesto podívat, kdo ji do Wikipedie vložil. K tomu slouží speciální nástroj Wiki Blame. ${ }^{23} \mathrm{~V}$ některých případech totiž encyklopedisté vystupují neanonymně (např́iklad známý český wikipedista a profesor Univerzity Karlovy Jan Sokol) a pak je možné citovat - místo Wikipedie - jako autora Jana Sokola. Prostředí MediaWiki softwaru umožňuje dohledat každou vloženou čárku a jejího autora (a u něj takové údaje, jako počet úspěšných editací atd.). $V$ jistém smyslu je tak méně anonymní než třeba články, pod nimiž je uvedeno množství autorů, ale není jisté, kdo co napsal. U zdrojů na bázi MediaWiki softwaru máme detailní přehled o všech aktivitách daného uživatele.

Další problém s citovaností/ověřitelností je, jak citovat. U řady článků se totiž setkáme s tím, že pod ním jsou uvedené reference, seznamy literatury, z nichž se při vytvoření textu čerpalo. Problém ale nastává, pokud chceme dohledat, odkud pochází konkrétní tvrzení. Nevíme totiž, z kterého z uvedených zdrojů pochází, popř. jestli vůbec z nějakého, zda autor v daném případě nečerpá jen ze svých vědomostí. Ač je to pro pisatele často jednodušší možnost než zdrojovat př́mo tvrzení obsažená textu, čtenáři pečlivé zdrojování přináší další dimenzi využitelnosti zdroje a na některých úrovních vzdělávání (jako například vysokoškolské) se často stává nezbytným pro možné využití daných informací.

Řádné citování respektovanými zdroji v daném oboru je tím, co textu zvyšuje jeho kvalitu (ve smyslu ověřitelnosti informací). Podobná praxe platí například v prestižních vědeckých článcích, kde se autoři v sekcích jako introduction většinou vyvarují nepodložených tvrzení a většinu výroků tak tvoří ty, jež jsou podloženy referencemi. Stejná praxe platí v nejlepších článcích na anglické Wikipedii, které se také vyznačují tím, že jsou raádně ozdrojované (viz Obrázek 6).

Obrázek 6. Ukázka dobré praxe zdrojování nejlepších článků anglické Wikipedie na úvodu článku Climate change.

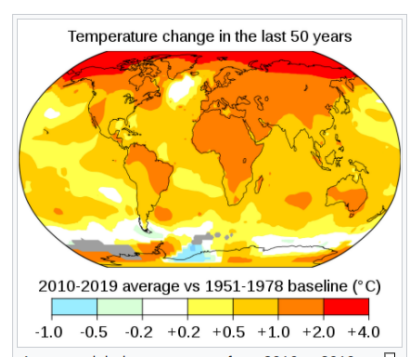

${ }^{23}$ https://en.wikipedia.org/wiki/Wikipedia:WikiBlame
} 
Dalším aspektem, podle nějž se můžeme orientovat při využívání OER MWS, je respektovanost použitých zdrojů. Ta se v př́ípadě vysokoškolského vzdělávání liší obor od oboru. Obecně ale platí, že spíše než zprávy v médiích by měly být uváděny zdroje respektované akademickou komunitou - např́íklad odborné knihy či články ve vědeckých časopisech. Pro orientační přehled hierarchie zdrojů může sloužit Hierarchie zdrojů Eatonové (Tabulka 10).

Tabulka 10. Tabulka respektovaných zdrojů pro studenty pedagogiky (Eaton, 2018), jež může být po modifikaci užitečná i pro vytváření OER MWS na vysokoškolské úrovni v jiných oborech

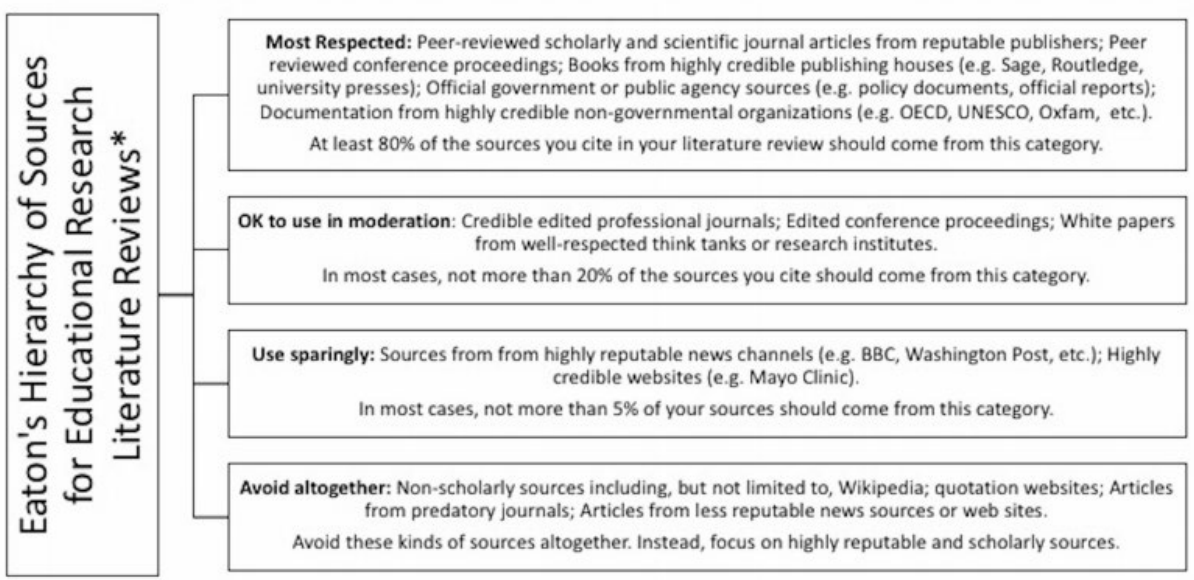

- This hierarchy is a general guideline, not a prescription. Every literature review will be different because every project is unique. Your professor may have their own ideas about the kinds of sources to include in your literature review. Consult with your professor. Sarah Elaine Eaton, Ph.D. is a faculty member at the Werklund School of Education, University of Calgary. The views expressed here are my own and do not necessarily reflect the views of the School of Education or the University of Calgary.

This work is licensed under a Greative Commons Attribution-NonCommercial-NoDerivatives 4.0 International License. (c) (1) (1)

\section{Aktuálnost}

Aktuálnost je klíčovým faktorem při využívání otevřených vzdělávacích zdrojů na bázi MediaWiki softwaru (OER MWS).

Právě možnost velice snadno aktualizovat obsah těchto zdrojů (a často prakticky kýmkoliv) je tím, co jim poskytuje konkureční výhodu oproti jejich uzavřenějším protějškům tedy zejména tištěným zdrojům, ale $v$ omezené míře i statickým webům z prostředí webu 1.0, jejichž aktualizaci často může provést pouze administrátor daného webu. Wikipedie a jiné OER MWS, ač vznikly také často již v počátcích rozvoje internetu, se řadí již do skupiny webových stránek označovaných jako web 2.0. Tedy zdrojů, které umožňují zapojení uživatelů do jejich tvorby a prípadné modifikace obsahu.

Význam aktuálnosti se dobře ukázal během covidové pandemie. Během několika týdnů vznikly na anglické Wikipedii přes čtyři tisíce článků o covidu, jež zaznamenaly přes 240 
milionů zobrazení (Wikimediafoundation, 2020). Přitom během jedné minuty v nich probíhalo často několik úprav, články tak byly prakticky nepřetržitě aktualizovány. $V$ tomto období z Wikipedie vycházel i Google ve svých grafech při zobrazování počtu nemocných v jednotlivých zemích.

$\mathrm{Na}$ Wikipedii se kolem koronavirových článků vytvořila spontánně komunita zdravotních expertů, kteří je kontrolovali, aby se do nich nedostaly nepodložené informace (Cohen, 2020). V období, v němž údajně i odborné vědecké časopisy často polevovaly v mechanismech zajišt'ování kvality a otiskly studie, které by za normálních okolností nemusely projít recenzním řízením, se tak Wikipedie stala jakýmsi gatekeeperem do světa znalostí o covidu. Článek Coronavirus disease 2019 na anglické Wikipedii editovalo celkem přes tisíc editorů a také řada robotů (algoritmů umělé inteligence), kteří dohromady provedli přes pět tisíc editací (viz Obrázek 7). Je zřejmé, že podobný mechanismus aktualizace obsahu by byl u tištěné publikace (nebo klasické elektronické) nerealizovatelný, stejně jako způsob její distribuce po celém světě v tak krátkém období. Vznikají nicméně i vědecké časopisy, které se vyznačuji rychlostí publikace, otevřeným přistupem i možnostmi otevřeného recenzního řízení (např. F1000). Články z nich pak mohou být rychle zakomponovány i do wiki systémů.

Obrázek 7. Statistika článku Coronavirus disease 2019 na anglické Wikipedii ${ }^{24}$

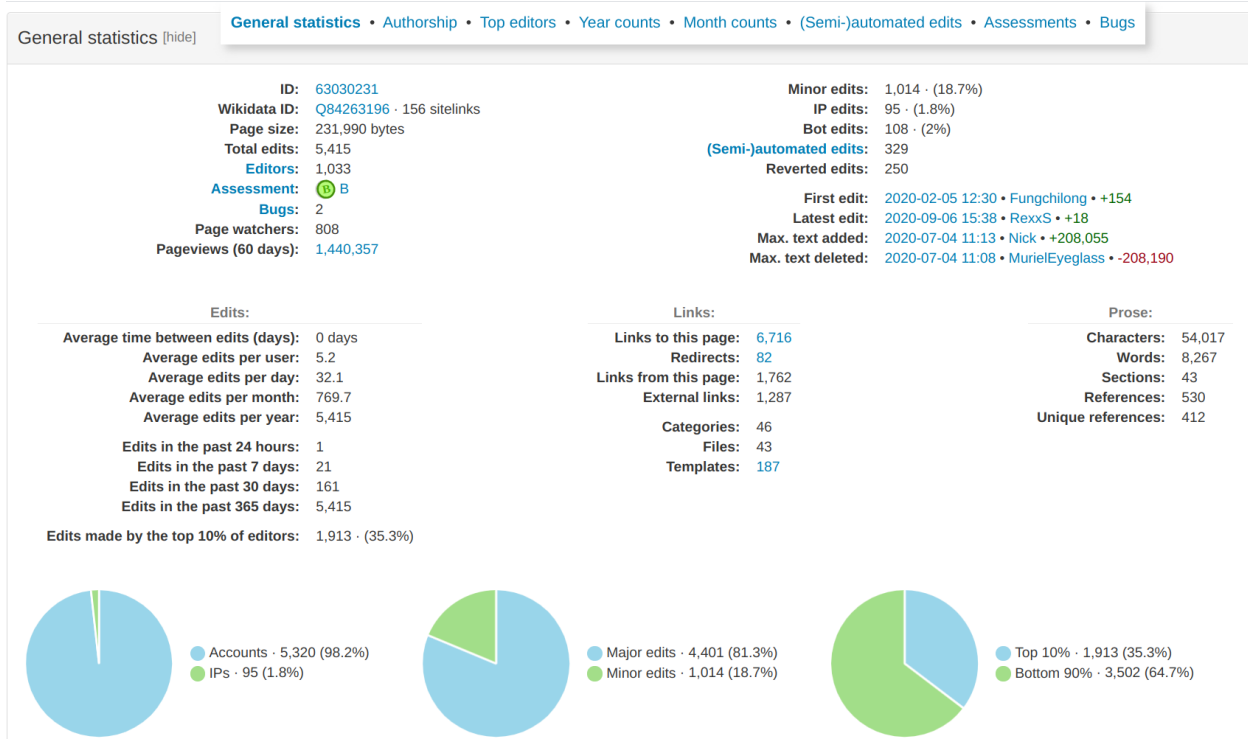

Při tvorbě obsahu OER MWS je možné využít také editační algoritmy (tzv. boti), které upozorňují uživatele na problematická slova, která napsal. V prípadě vandalismu to mohou být například vulgarismy, nicméně editační algoritmy jsou užitečné právě i pro zajištění

${ }^{24}$ https://xtools.wmflabs.org/articleinfo/en.wikipedia.org/Coronavirus disease 2019 
aktuálnosti. Editační boti upozorňují editora na podobná slova jako letošní, nynější, aby se jich uživatel vyvaroval a text v budoucnu nepůsobil zastarale.

V príipadě využívání a citování OER MWS platí, že kromě citace času přístupu - či poslední aktualizace článku, ze kterého vycházíme - je vhodnější s tímto údajem uvádět rovněž specifické číslo stránky (tzv. ID), jež můžeme nalézt v historii editací. Uvádění tohoto data garantuje, že případný zájemce o citaci najde přesně tu verzi, ze které vycházíme. Jak již bylo uvedeno, v prípadě OER MWS může proběhnout více editací v průběhu jedné minuty, nemusí tak stačit citovat nejen hodinu, ale ani minutu prístupu.

Obecně platí, že pokud si chceme ověřit to, zda je zdroj, jejž chceme využít, aktuální, máme tři možnosti jak to poznat:

- Obsah - V případě obsahu vidíme v článku často časové údaje, které jsou v některých př́padech užitečným indikátorem aktuálnosti. Zvláště pokud čteme text o problematice, u níž předpokládáme, že se poznání o ní v čase vyvíjí (např. článek Climate change na anglické Wikipedii), a ve vlastním textu článku by byl poslední časový údaj z dávné minulosti (např. před rokem 2000), přičemž se problematika o níž pojednává vyvijí, můžeme vytušit, že zdroj není pravidelně aktualizován nejnovějšími informacemi.

- Reference - Reference jsou užitečným indikátorem aktuálnosti. Stačí se podívat na datum jejich publikace a zjistit tak, zda je některá z posledního období.

- Historie editací - Historie editací je nejlepším indikátorem, zda se s článkem „něco děje" ve smyslu, že o se o něj někdo stará. Historie bývá v př́padech OER MWS často vpravo nahoře (Obrázek 8). Pokud ji rozklikneme, podle časových údajů poznáme, kdy byla vytvořena poslední aktualizace, popř. zda je článek průběžně upravován.

Zároveň je ale třeba si uvědomit, že ne všechny články je potřeba aktualizovat. U některých témat se poznání již tolik nevyvijí, a i když zdroj není pravidelně aktualizován, na kvalitě mu to nemusí uškodit.

Obrázek 8. Ilustrace možnosti zobrazení historie editací na článku Global Warming na anglické Wikipedii přes pole View history (zakroužkováno červeně) 

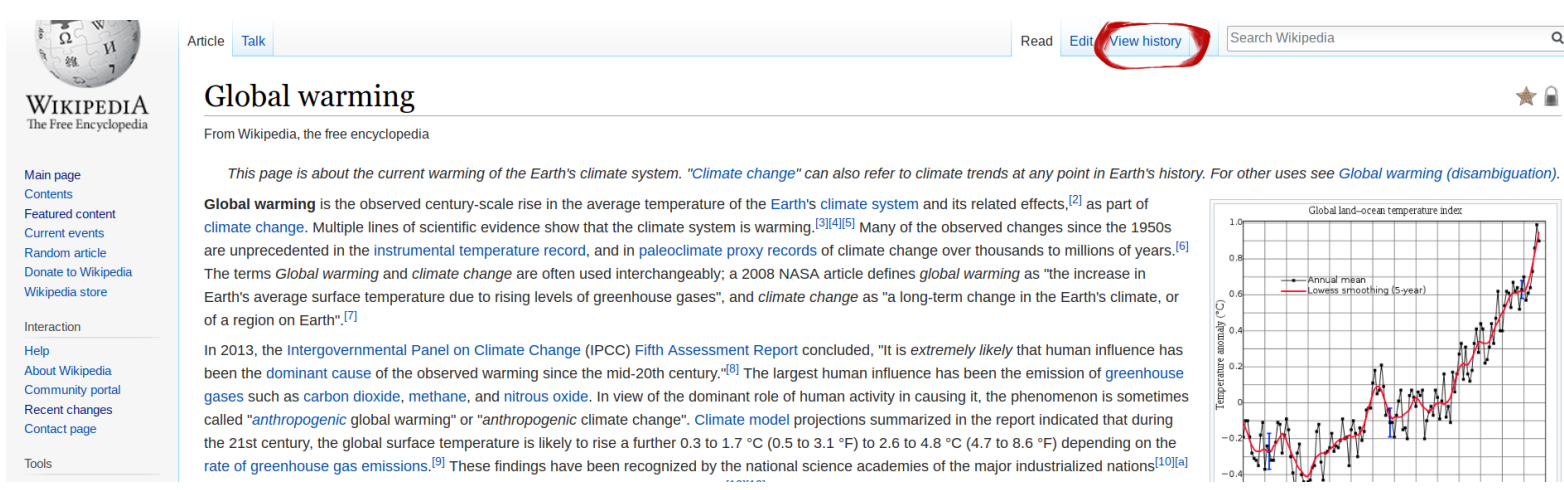

\section{Nezaujatost}

Při výběru vhodných otevřených vzdělávacích zdrojů na bázi Mediawiki softwaru (OER MWS) hraje důležitou roli objektivita čili neutrální úhel pohledu (anglicky: neutral point of view). Zdroj by neměl opomíjet žádný pohled na problematiku, pokud jsou tyto názory ve veřejné debatě rovnoměrně zastoupeny.

Právě objektivita, tedy nestranné objektivní pojednání o specifické problematice, je důležitá pro edukativní účely, a to zejména v procesu vysokoškolského vzdělávání, kdy by studenti měli studovat ze zdrojů, které nejsou vytvářeny za účelem reklamy či propagace nějakého názoru na úkor jiného, jenž je pro dané účely stejně relevantní. OER MWS zároveň skýtají značné nebezpečí, že si jejich tvưrci budou snažit prosadit svou a obsah záměrně odchylovat od objektivní linky směrem ke svému přesvědčení. Změna textu je relativně jednoduchá, proto mnohé svádí toho využít k svému cíli. To je problém zejména u široce prístupných OER MWS, jako je Wikipedie, ale u zdrojů, jež jsou vytvářeny $v$ rámci vysokoškolského prostředí není toto riziko tak velké.

Objektivita je proto jedním ze základních požadavků i např́iklad při tvorbě článků na Wikipedii. ${ }^{25}$ Články, které nesplňují požadavky na neutralitu, by měly být přepracovány. Obecně platí, že stejně jako Wikipedie by ani jiné OER MWS neměly být využívány jako prostor pro propagaci nepodložených názorů. Naopak všechny názory, jež nejsou tzv. společnou znalostí (tj. všeobecně známé), by měly být podloženy seriózními zdroji, nejlépe pak výsledky relevantního vědeckého výzkumu (to zejména při využití pro vysokoškolské účely).

Objektivita zároveň neznamená, že je do OER MWS třeba zahrnout všechny názory na danou problematiku. To platí zejména o názorech, jež jsou ve veřejné debatě zcela marginální a nemají oporu ve faktech. Například v článku o zakřivení Země není třeba uvádět,

\footnotetext{
${ }^{25}$ Přitom u oborů, jako je například životní prostředí, záleží na tom, jaké hodnoty dané téma zohledňuje a prosazuje. Hodnotové hledisko by mělo být sledováno a korigováno, naprííklad když obsah tvoří samotní studenti. To je rozdíl třeba od článků pro Wikiskripta, kde jsou témata více hodnotově neutrální.
} 
že tento fakt zpochybňuje jistá skupina obyvatel, jež zakřivení Země popírá a je přesvědčena, že ve skutečnosti je Země placatá.

Pro zachování objektivity je důležité alespoň částečný souhrn poznatků ze zdrojů, jež jsou v dané problematice široce uznávané a respektované (u vědeckých článků je naprííklad možné využít jako indikátor jejich celkovou citovanost, jelikož nejcitovanější práce tvoří obvykle základ a jádro oboru - stejně jako autoři těchto prací). To, jak obsáhlý by tento souhrn měl být, značně variuje a záleží zejména na cílové skupině, pro niž je zdroj vytvářen. 


\section{Vytváření OER MWS}

\section{Žánr}

Při tvorbě OER MWS je vhodné si nejprve ujasnit žánr, který má být vytvořen (například skripta, případová studie či encyklopedické heslo). Jak již bylo zmíněno, tyto zdroje mohou do jisté míry představovat nový typ žánru, pokud využijeme nových možností, které poskytuji oproti zdrojům klasickým tištěným. Je sice možné tyto výhody nevyužít a pouze „překlopit” tištěná skripta do digitální podoby, $v$ tom případě ale není nutné vytvářet tento typ zdrojů. OER MWS jsou vhodné například pro zdroje, které funguji jako encyklopedie (Wikipedie), v prípadě vysokoškolských materiálů se pak nabízí jejich využití pro vytváření různých zdrojů na bázi skript (v českém prostředí např. Wikiskripta), která se ale od klasických tištěných skript liší v řadě ohledů - například snadným přesměrováním na související témata, přidáváním různých mediálních přiloh (například videí) a zejména možností neustálé aktualizace.

\section{Obsah a uživatelé}

Obsahová stránka je při vytváření OER zásadní. Aby zdroj mohl dobře posloužit účelu, pro který je vytvářen, je potřeba si na prvním místě položit klíčové otázky: „Pro koho je daný zdroj vytvářen?” či „Kdo mají být jeho uživatelé?” Tyto otázky, jakkoliv se mohou zdát triviální, rozhodují o celém dalším osudu OER. Témata se dají zpracovat tak, aby vyhovovala rozmanitým informačním potřebám - od studentů základních škol až po doktorandy. Je ale potřeba si cílovou skupinu předem zvolit, protože není snadné vytvořit zdroj pro všechny, aniž by utrpěla kvalita ve smyslu využitelnosti daného zdroje ke specifickým vzdělávacím potřebám. Aby zdroj vyhověl definici kvality ve smyslu fitness for use, to je klíčový záměr jeho tvưrce.

\section{OER MWS, nebo Wikipedie?}

Definicí cílové skupiny a účelu, jemuž má zdroj sloužit, se může odlišit konkrétní OER MWS projekt od široce využívaných zdrojů, jako je např. Wikipedie. Největší encyklopedie totiž nemá jasně vymezenou cílovou skupinu a jejím účelem je být „encyklopedií pro všechny”. Pokud designovaný OER MWS nemá vyhraněný účel a specifikovanou skupinu, pro niž je navržen, hrozí, že se stane více či méně kvalitní kopií Wikipedie. Lepší než vytvářet podobné heslo, jaké je na Wikipedii, na vlastním OER MWS, je zapojit se do jeho tvorby na Wikipedii. Ta má totiž již lépe fungující komunitu, a je proto pravděpodobnější, že se o článek bude starat 
a aktualizovat jej. To může být prínosnější zvláště v případě, pokud není zajištěna dlouhodobá udržitelnost projektu jak z hlediska finančního, tak personálního zázemí.

Wikipedie je zdaleka nejvyužívanější OER MWS, je proto vhodné se s jejím fungováním seznámit i při vytváření alternativních OER MWS. Například její pravidla na řešení sporů, vytváření a úpravy obsahu patří $\mathrm{k}$ tomu nejlepšímu, co bylo $\mathrm{v}$ rámci OER WMS vytvořeno. Pro základní orientaci v této problematice může zájemce čerpat ze stránky Five pillars na anglické Wikipediii ${ }^{26}$ či Pět pilírư v její české mutaci. ${ }^{27}$

Obecně Ize konstatovat, že Wikipedie se hodí jako obecný úvod do tématu, tedy encyklopedické shrnutí, jak je také designována, kdežto výhoda vytváření alternativních OER MWS vynikne ve specializovaných tématech, zejm. pokud mají ambici pokrývat spektrum znalostí, které najdou konkrétní využití například při zkoušce, takže mohou sloužit do určité míry jako alternativa k papírovým skriptům (viz český projekt lékařských fakult WikiSkripta ${ }^{28}$ ).

Wikipedie (a další projekty Wikimedia Commons) mohou také sloužit jako vhodný doplněk při vytváření vlastních OER MWS. A obráceně (viz Obrázek 9) při tvorbě vlastních zdrojů je možné využít text $z$ Wikipedie a média z Wikimedia Commons. A pokud jsou námi vytvářené OER MWS pod otevřenou licencí, je možné kopírovat z nich části do Wikipedie $s$ odkazem na původní zdroj (a tak zároveň i zvyšovat návštěvnost alternativních OER MWS projektů). Při vytváření OER MWS je možné také využít studenty - viz např́iklad projekt Studenti píší Wikipedii. ${ }^{29}$

Obrázek 9. Diagram znázorňující možné vztahy mezi OER MWS, Wikipedií a dalšími zdroji

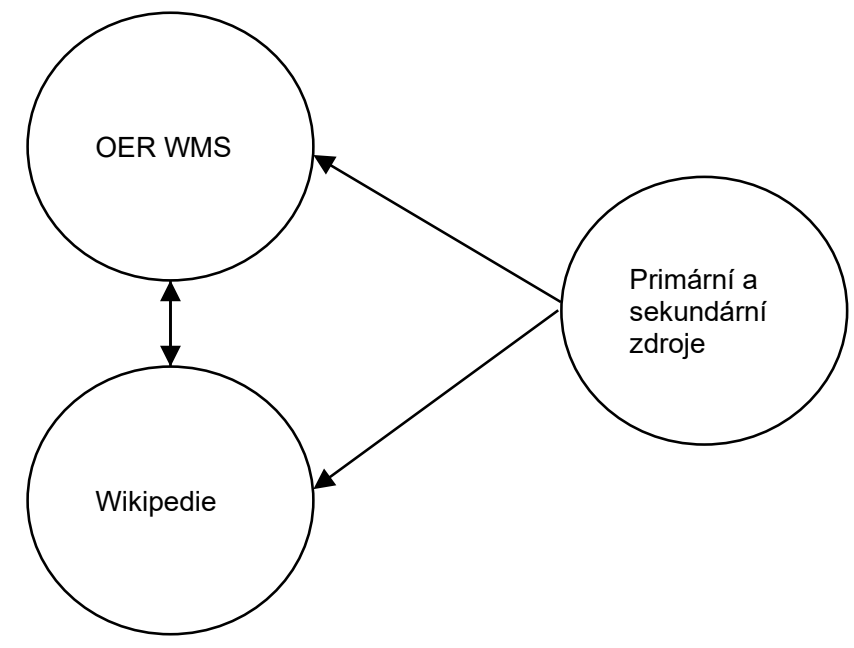

${ }^{26}$ https://en.wikipedia.org/wiki/Wikipedia:Five pillars

${ }^{27}$ https://cs.wikipedia.org/wiki/Wikipedie:P\%C4\%9Bt pil\%C3\%AD\%C5\%99\%C5\%AF

$28 \mathrm{https://www.wikiskripta.eu/w/Home}$

${ }^{29}$ https://cs.wikipedia.org/wiki/Wikipedie:Studenti_p\%C3\%AD\%C5\%A1\%C3\%AD Wikipedii 


\section{Uvedení data a ID vytváření a editace}

Při vytváření OER MWS jsou časové údaje u jednotlivých částí textu klíčové. Umožňují identifikovat jak jednotlivé editace a verze stránky, tak tvưrce konkrétních částí textu, popř. autory úprav.

OER MWS umožňují zobrazovat časové údaje o vytváření textu, jeho úpravách a změnách v položce „Zobrazit historii”, která se objevuje u stránky nad textem vpravo nahoře (pokud není naprogramováno jinak). Právě přes tuto položku je možné rozkliknout si jednotlivé historie editací a porovnávat různé verze, popř. najít kdo a kdy přidal konkrétní část textu. Údaje o poslední editaci mohou být ale často zavádějící, protože OER MWS nefunguje jako klasický text a datum poslední editace ještě neznamená, že v tuto dobu text prošel poslední celkovou revizí (editor mohl změnit třeba pouze překlep). Proto je lepší odkázat prípadné zájemce o časové údaje jednotlivých úprav na kompletní historii editací.

V případě uvádění časového údaje OER MWS nabízí i možnost uvedení specifické verze (ID - identifikačního čísla konkrétní stránky). Při prípadné další práci s konkrétním textem (stránkou na OER MWS), například při jejím citování, je pak vhodné neuvádět pouze časový údaj, ale též identifikační číslo (ID) dané stránky, protože v rámci OER MWS mohou proběhnout více než dvě editace během jedné minuty. ID stránky tak slouží jako lepší identifikátor konkrétní verze než pouhý čas její poslední editace. Citace stránky Wikipedie na anglické Wikipedii tak může vypadat například takto: „Přispěvatelé Wikipedie. (2020). Wikipedia. Wikipedia. ID citované verze stránky: 934425180. https://en.wikipedia.org/wiki/Wikipedia."

\section{Využívání hypertextu}

Hypertext hraje při vytváření OER MWS významnou úlohu. Podobně jako u jiných digitálních zdrojů je jednou z hlavních deviz OER MWS oproti klasickým studijním zdrojům, jako jsou tištěná skripta. Problematika hypertextu je již diskutována v rámci této metodiky $v$ relevantní kapitole Specifický žánr textu. Pokud je hypertext při vytváření textu správně využíván, může mít značně pozitivní efekt. Mưžeme definovat tři hlavní výhody, které při tvorbě a využívání OER poskytuje:

- Interdisciplinární myšlení - Formou hypertextu je možné snadné přesměrování na související témata, čtenář je tak veden $k$ holistickému přemýšlení v kontextu. Nestuduje pouze danou látku, ale je mu prezentován i širší kontext a souvislosti.

- Inkluzivní přístup - Hypertext pomáhá jisté demokratizaci studijního materiálu. Je totiž možné dát složitější text i studentovi, který je ve srovnání s jinými čtenáři méně vzdělaný v dané problematice. Jestliže nějakému výrazu 
nerozumí, může ho rozkliknout a poučit se o něm. A naopak čtenáři, kteří jsou vzdělanější, nemusí být zdržováni zbytečným vysvětlováním toho, co již znají. Vzhledem k tomu, že dnešní studenti přichází z rozličných kulturních a sociálních prostředí, může jim studium z OER MWS, jež dobře využívá možností hypertextu, pomoci sjednotit jejich znalosti na požadovanou úroveň. Hypertext tímto zároveň může také sloužit na způsob určitého slovníku neznámých pojmů.

- Ověřitelnost tvrzení - Díky hypertextu se dá lehce označit tvrzení v článku prostřednictvím zdroje u něj uvedeného. Každý se tak může jedním kliknutím přesvědčit, zda ono tvrzení je skutečně obsaženo $v$ uvedeném zdroji, a případně si ho přečíst v patřičném kontextu.

\section{Důsledné zdrojování}

Uživatelské prostředí OER MWS umožňuje zdrojovat jak jednotlivé části textu, tak uvádět pod vytvořený text literaturu. Při vytváření OER MWS je vhodné zvážit důsledné zdrojování jednotlivých tvrzení, a to zejména v př́padě, že se jedná o zdroje, jež umožňují hromadnou anonymní kolaborativní editaci.

Důležitější než kdo obsah přidá, pak totiž může být to, čím je daná část obsahu ozdrojována (jak kvalitním zdrojem). Právě možnost ověřit si snadno tvrzení formou přidání reference je dalším významným benefitem těchto zdrojů. Zejména pokud se jedná o vysokoškolské materiály, je důsledné zdrojování na místě vzhledem k tomu, že studentům Ize jen těžko doporučit anonymní zdroje, v nichž převažují neozdrojovaná tvrzení. Pro pečlivé zdrojování obsahu v případě vytváření zdroje pro vysokoškolské účely svědčí následující argumenty (Tabulka 11).

Tabulka 11. Popis důvodů pro odkazované maximální výroky respektovanými zdroji v anonymních zdrojích, jako je Wikipedie (dle Petiška, Moldan, 2019)

\begin{tabular}{|l|l|}
\hline Důvody & Popis důvodů \\
\hline Problém ověřitelnosti & $\begin{array}{l}\text { Neznáme autora konkrétního prohlášení, } \\
\text { a proto není důvod, proč bychom mu měli věřit. } \\
\text { Pokud mǔžeme tvrzení ověrit z respektovaného } \\
\text { zdroje, mǔžeme mu důvěřovat. }\end{array}$ \\
\hline Problém společné znalosti & $\begin{array}{l}\text { a) Je nemožné definovat společnou znalost ve } \\
\text { zdrojích, které využívají studenti různých oboru a } \\
\text { rưzných prostředí. } \\
\text { b) Studenti by měli použíivat především zdroje, } \\
\text { které obsahují minimum společných znalostí a } \\
\text { maximum nových informací. }\end{array}$ \\
\hline
\end{tabular}




\begin{tabular}{|c|c|}
\hline Rozcestník a přehled literatury & $\begin{array}{l}\text { Anonymní zdroje by měly být na vysokoškolské } \\
\text { úrovni doporučeny pouze jako rozcestník k jiným } \\
\text { zdrojủm a pro přehled literatury. }\end{array}$ \\
\hline Kontext informací & $\begin{array}{l}\text { Informace bez kontextu jsou méně hodnotné. } \\
\text { Studenti by se měli naučit nejen popis reality, ale } \\
\text { také jeho vysvětlení. Zdroj jim může pomoci } \\
\text { pochopit kontext. }\end{array}$ \\
\hline Kritické myšlení & $\begin{array}{l}\text { Studenti by měli pochopit, že informace bez } \\
\text { uvedení zdroje jsou méně důvěryhodné než } \\
\text { informace z respektovaného zdroje. }\end{array}$ \\
\hline Problém plagiarismu & $\begin{array}{l}\text { Neozdrojovaná tvrzení lze získat z jiných zdrojů } \\
\text { bez jejich přiznání. Toto použití je neetické, a } \\
\text { někdy i nezákonné. }\end{array}$ \\
\hline Problém citogeneze & $\begin{array}{l}\text { Problém kruhového zdrojování: neozdrojované } \\
\text { tvrzení v anonymním zdroji je použito v jiném } \\
\text { zdroji a ten pak zpětně použit pro ozdrojování } \\
\text { původního tvrzení v anonymním zdroji. }\end{array}$ \\
\hline Špatná praxe & $\begin{array}{l}\text { Studenti, kteří používají neozdrojované } \\
\text { informace z anonymních zdrojů, se mohou naučit } \\
\text { špatnou praxi i v jiné části svého vzdělávacího } \\
\text { procesu nekritické prínetín informací, } \\
\text { a) norín } \\
\text { b) plagiátorství (mohou si zvyknout používat } \\
\text { informace bez zdroje i ve své diplomové práci). }\end{array}$ \\
\hline
\end{tabular}

\section{Mediální príloha}

OER MWS umožňují vkládat k textu rozmanité mediální přílohy, jako jsou obrázky, videa či zvukové soubory. Při vkládání těchto souborů je nicméně třeba mít na paměti licence, pod nimiž je obsah licencován, a zda jsou tyto licence kompatibilní s licencí zdroje, jejž vytváříme (viz kapitola Otevřené licence).

\section{Cílová skupina}

Definování cílové skupiny je zásadní pro tvorbu OER MWS. Právě ta určuje, na co se zaměřit při tvorbě obsahu. Pokud jsou naší cílovou skupinou studenti, je vhodné zkoumat jejich požadavky na studium. Čím přesněji je cílová skupina definována, tím lépe se dá zdroj zaměřit. Například úspěch českých WikiSkript je do značné míry dán tím, že mají přesně vymezenou cílovou skupinu, pro niž zdroj vytváří - studenty lékařských fakult. 


\section{Aktéři}

V rámci tvorby zdroje je třeba definovat jeho aktéry a role, které v projektu zastávají. Ty mohou variovat od tvưrců a recenzentů až po projektové manažery případně team leadery a organizační pracovníky. OER MWS skýtaji potenciál pro řadu dalších aktérů oproti klasickým tištěným či digitálním zdrojům (např. IT specialista, kontrolor vandalismu atd.).

\section{Hierarchie}

V rámci OER MWS je možné konstruovat hierarchii jednotlivých vztahů mezi aktéry. Mělo by být jasné, kdo je zodpovědný za který prvek fungování systému. V rámci těchto zdrojů se nejlépe osvědčuje tzv. plochá hierarchie či přístup bottom up. Tedy, že tyto zdroje fungují nejlépe na vnitřní motivaci svých členů, a nikoli na centrálním řízení shora. Podporován je princip subsidiarity, což $v$ tomto případě znamená řešení problémů při jejich vytváření na nejnižší možné úrovni (typicky tak, že chybu opraví první editor, který si jí všimne). V rámci OER MWS můžeme vyčlenit několik rolí v rámci hierarchie týmu, který daný zdroj vytváří (Tabulka 12).

Tabulka 12. Popis možných aktérů OER MWS.

\begin{tabular}{|l|l|}
\hline Role & Popis role \\
\hline Iniciátor, vedoucí projektu & $\begin{array}{l}\text { Iniciátor je v každém OER MWS projektu } \\
\text { klíčovou osobou. Právě on přichází s inovací } \\
\text { v podobě vytvoření těchto zdrojů a jeho úlohou je } \\
\text { přesvědčit své okolí o jejich výhodách } \\
\text { a motivovat své kolegy k zapojení. }\end{array}$ \\
\hline Ambasador & $\begin{array}{l}\text { Aktér, který šírí osvětu a motivuje potenciální } \\
\text { zájemce k zapojení do projektu. Mohou to být } \\
\text { napríiklad učitelé, studenti nebo wikipedisté } \\
\text { (v rámci projektu Studenti píší Wikipedii). }\end{array}$ \\
\hline Vedoucí práce & $\begin{array}{l}\text { Zadává a kontroluje vytváření obsahu } \\
\text { (konkrétních článků). Může to být např́klad }\end{array}$ \\
\hline
\end{tabular}

${ }^{30}$ Role iniciátora je značně specifická - mezi jeho kompetence by mělo patřit projektové řízení a schopnost motivovat ostatní. $V$ ideálním prípadě by měl být ukotven ve strukturách organizace, jež konkrétní projekt zastřešuje. Nalézt schopného iniciátora patří k nejdůležitějším a zároveň nejtěžším aspektům tvorby těchto zdrojů. 


\begin{tabular}{|c|c|}
\hline & $\begin{array}{l}\text { učitel, který vede své studenty } v \text { hodinách } \\
\text { k vytváření jednotlivých textů. }\end{array}$ \\
\hline Nováček - student & $\begin{array}{l}\text { Nově zapojený účastník projektu, kterému je } \\
\text { třeba poskytnout metodickou oporu. Na } \\
\text { průběžném zapojování nováčků stojí celá } \\
\text { komunita wiki systémů. }\end{array}$ \\
\hline Editor & $\begin{array}{l}\text { Může jím být jak student přispívající na } \\
\text { dobrovolné bázi, tak placený editor obsahu. }\end{array}$ \\
\hline Redaktor & $\begin{array}{l}\text { Ze zkušených editorů se stávají redaktoři, kteří } \\
\text { dohlíží na tvorbu obsahu, vybírají články } \\
\text { k založení či rozšíření a aktualizaci. }\end{array}$ \\
\hline Správce & $\begin{array}{l}\text { Správce projektu odpovídá za spravování } \\
\text { projektu po technické správce, blokuje prípadné } \\
\text { vandaly a dává práva jednotlivým uživatelům. }\end{array}$ \\
\hline Administrátor & $\begin{array}{l}\text { Administrátor má na starosti finanční a právní } \\
\text { věci spojené se zajištěním projektu. }\end{array}$ \\
\hline Recenzent & $\begin{array}{l}\text { Expert, který se podílí na recenzi vytvořených } \\
\text { materiálů, a zvyšuje tak kvalitu obsahu. }\end{array}$ \\
\hline Technická podpora & $\begin{array}{l}\text { IT pracovník dohlížející na průběžné aktualizace } \\
\text { MediaWiki softwaru. }\end{array}$ \\
\hline Široká veřejnost & $\begin{array}{l}\text { Každý kdo se chce zapojit do tvorby obsahu či } \\
\text { jeho modifikace (např. jen opravením } \\
\text { gramatiky). }{ }^{31}\end{array}$ \\
\hline Technologie (umělá inteligence, boti atd.) & $\begin{array}{l}\text { Software detekující vandalismus a nevhodná } \\
\text { slova. }\end{array}$ \\
\hline
\end{tabular}

Z výše uvedeného přehledu je patrné, že role v redakčním týmu jsou různorodé a jen některé souvisí se zajištěním kvality obsahu. Expertiza jednotlivých členů týmu se značně liší, a prritom by $v$ ideálním prípadě mělo být pokryto celé spektrum potřebných specializací. Slučování rolí s sebou nese rizika neodborného přístupu; z toho vyplývá, že pro zajištění

\footnotetext{
${ }^{31}$ I v případě široké veřejnosti se ale může jednat o experty (např. WikiSkripta editují i začínající lékaři).
} 
celkové kvality zdroje je potřeba mít poměrně početný tým. ${ }^{32}$ Toto pravidlo platí ještě více tam, kde zdroj má mít větší rozsah - tuto kvantitu pak zajišt'uje větší množství přispěvatelů a úměrně tomu i dalších členů týmu, kteří jejich příspěvky korigují. Když je však dosaženo určité „nadkritické masy” těch, kteři se věnují posuzování textů, může k opravám chyb a nepřesností docházet velmi účinně (dokonce rychleji a přesněji než u zdrojů garantovaných menším počtem vysoce kvalifikovaných odborníků). Pak je dosaženo bodu, kdy kvantita může přerůst v kvalitu.

\section{Redakční tým}

Redakční tým je tedy základem, na němž OER MWS stojí. Právě členové redakce totiž zodpovídají za správu a údržbu zdroje. Jejich práce se dá rozdělit do následujících bodů:

- vytváření nových článků,

- kontrola stávajících článků před vandalismem (t.j. vkládání vulgárního či jinak nevhodného obsahu),

- aktualizace stávajících článků novými poznatky.

Způsob fungování redakce má také přímý vliv na dlouhodobou udržitelnost zdroje. Právě udržitelnost představuje jeden z největších problémů při vytváření OER MWS. Na začátku vytváření těchto projektů může panovat jisté idealistické nadšení, třeba ještě podpořené účelovou finanční podporou poskytnutou na vznik projektu. $V$ průběhu let se ale nadšení i finance začínají v mnoha prípadech vytrácet. Zdroj pak v lepším případě aktualizují přiležitostní návštěvníci, $v$ horším se stane předmětem útoků vandalů a začne po stránce kvality značně upadat. Dobrým krokem k zajištění funkční komunity pak může být například zapojit do vytváření OER MWS studenty. Ukazuje se nicméně, že v tomto případě nejlépe funguje dobrovolná spolupráce (příklad dobré praxe zajištění udržitelnosti zdroje opět představují například Wikiskripta ${ }^{33}$, která mají také z českých OER MWS největší a nejlépe fungující komunitu, založenou právě na dobrovolnosti). Komunity zdrojů je možné analyzovat pomocí metody analýzy aktérů (pro ilustraci viz Tabulka 13).

\footnotetext{
${ }^{32}$ Zároveň ale není nutné, aby každou funkci zastával někdo jiný. Důležité je, aby byly jednotlivé funkce přiřazeny a jednotliví aktéři měli na vykonávání své činnosti přiměřené časové možnosti.

${ }^{33}$ https://www.wikiskripta.eu/w/Home
} 
Tabulka 13. Výsledky analýzy aktérů OER MWS na Univerzitě Karlově zaměřené na jednotlivé aspekty kvality (dle Petiška a kol., 2020)

\begin{tabular}{|l|l|l|l|l|l|}
\hline Název zdroje & WikiSkripta & $\begin{array}{l}\text { Studenti píší } \\
\text { Wikipedii }\end{array}$ & Wikisofia & $\begin{array}{l}\text { WikiKnihovna } \\
\mathbf{1}\end{array}$ & Enviwiki \\
\hline $\begin{array}{l}\text { Garant } \\
\text { kvality }\end{array}$ & $\begin{array}{l}\text { Komunita } \\
\text { (zejm. medici) }\end{array}$ & Pedagog & Redakční rada & Studenti & $\begin{array}{l}\text { Recenze } \\
\text { odborníků }\end{array}$ \\
\hline $\begin{array}{l}\text { Hodnocení } \\
\text { kvality } \\
\text { kdo } \\
\text { hodnotí) }\end{array}$ & $\begin{array}{l}\text { Komunitní } \\
\text { hodnocení }\end{array}$ & $\begin{array}{l}\text { Komunitní } \\
\text { hodnocení }\end{array}$ & $\begin{array}{l}\text { Hodnotí } \\
\text { koordinátor }\end{array}$ & Studenti & $\begin{array}{l}\text { Hodnocení } \\
\text { odborníkem }\end{array}$ \\
\hline $\begin{array}{l}\text { Zajištění } \\
\text { spolehlivo } \\
\text { sti informací }\end{array}$ & $\begin{array}{l}\text { Komunita } \\
\text { a recenzenti }\end{array}$ & Komunita & Redakce & Editoři & $\begin{array}{l}\text { Redakce } \\
\text { a recenzenti }\end{array}$ \\
\hline
\end{tabular}

\section{Komunita}

Sladěný redakční tým je nezbytný jak pro vytváření jednotlivých OER MWS, tak zejména pro zajištění udržitelnosti jejich provozu. Mưže fungovat zcela volně a anonymně, anebo být částečně organizovaný a korigovaný. Bez vyváženého, dlouhodobě fungujícího týmu tyto zdroje stagnují a v př́padě vandalismu, který bývá detekován právě jeho členy, mohou být i lehce poškozovány.

Redakční tým u otevřených vzdělávacích zdrojů však může nabývat povahy komunity - u téměř všech rolí se předpokládá osobní iniciativa a alespoň role iniciátora by měla být spojena se schopností vést a tmelit kolektiv, být hybnou silou celého projektu. Projekty, které taková osobnost vede, pak svým účastníkům přinášejí uspokojení ze spolupráce, kdy každý přispívá dle svých schopností. Vědomí společného díla pak může být posilováno různými morálními pobídkami (například postupem v hierarchii odpovědnosti), a není tak plně závislé na finančním ohodnocení. V ideálním prípadě se potom utváří demokratické společenství, v němž si jsou všichni rovni, což zajišt'uje kolektivní recenzování daného zdroje i debatu nad jeho dalším rozvojem. Každý člen komunity může cokoliv upravit, protože nad úpravami je zajištěn mnohostranný dohled; o složení týmu (vymezení a změně rolí) se diskutuje společně.

A přestože se jedná o zdroje digitální a komunita funguje v rámci online prostředí, její setkávání ve fyzickém světě může mít pozitivní vliv na OER WMS projekty. Proto také tyto projekty pořádají často workshopy či konference i různá neformální setkání. V prípadě české Wikipedie například setkání Pod reálnou Lípou. ${ }^{35}$

\footnotetext{
${ }^{34} U$ WikiKnihovny je popsána původní idea, projekt je v současné době nefunkční (webové stránky jsou stále $v$ provozu, ale již nejsou pravidelně aktualizovány).

${ }^{35}$ Stránka Pod reálnou Lípou na české Wikipedii, na niž se domlouvají neformální setkání.
} 


\section{Propagace zdroje}

Komunikaci OER MWS a priilákání dalších návštěvníků k těmto zdrojům napomáhá jejich struktura a princip wiki. Jednotlivé stránky fungují samy o sobě a prostřednictvím hyperlinků na sebe odkazují. Právě odkazy jsou důležité pro optimalizaci vyhledávačů (tzv. SEO). OER MWS se tak často objevují na prvních příčkách Googlu ve výsledcích tematického vyhledávání. Při komunikaci článků je možné využít například spolupráci s Wikipedií a vkládat do relevantních článků části obsahu vytvářeného OER MWS s odkazem na původní článek, a tak přispět k lepší dohledatelnosti vytvářeného zdroje.

\section{Otevřenost}

OER MWS fungují nejlépe na principu široké otevřenosti. Čím větší participaci na vytváření obsahu umožňují, tím lépe využívají hlavní devizu těchto zdrojů - možnost široké spolupráce při kolaborativním vytváření obsahu. Otevřenost má ale také určitá omezení a problémy, jako např́iklad ničení obsahu internetovými vandaly. Široká otevřenost by proto měla být vyvážena dobře fungující komunitou, která případné chyby a úmyslná poškození zdroje opravuje.

\section{Motivace}

Z námi provedené analýzy aktérů vyplynulo, že v prípadě zapojení do komunity a vytváření OER MWS nejlépe funguje vnitřní motivace, tedy že účastník se zapojí sám na dobrovolné bázi. Naopak se neosvědčuje jakákoliv forma donucení, například vytváření těchto zdrojů $v$ rámci školních povinností. $V$ takovém prípadě se studenti sice do tvorby vytváření zdrojů zapojí a vytvoří požadovaný obsah, v projektu ale po skončení povinnosti již nezůstávají, a nestanou se tak plnohodnotnými členy komunity (jak je vidět na príkladě WikiSkript).

\section{Ocenění}

Vnitřní motivace tvorby zdroje může být podpořena a ohodnocena různými oceněními, která je možné v rámci OER MWS udělit členům komunity. $A$ to jak za výsledek činnosti např. ohodnotit vytvořený obsah ve formě poděkování za editaci, tak přímo členu komunity za jeho dlouhodobou činnost (různé medaile a řády, které si pak uvádí na své uživatelské stránce $v$ daném OER MWS). Doplňky ocenění může představovat finanční odměna či kredity ( $v$ rámci studia), tyto doplňky ale zpravidla nepředstavují hlavní motivaci $k$ vytváření OER WMS a nemohou nahradit vnitřní motivaci. 


\section{Uvádění autorství}

V případě tvorby článků je třeba vhodné zvážit, zda a jakým způsobem se uvede autorství, popř. recenze odborníkem. Pokud je u článku uveden autor a je možnost zdroj dále upravovat, vyvstává problém, že článek může být výrazně změněn jiným editorem, aniž by o tom původní autor věděl. A čtenář tak může být mystifikován, protože má za to, že text, který čte, byl celý napsán uvedeným autorem. Stojí proto za zvážení, jak tento problém vyřešit. V případě široké otevřenosti zdroje (možnosti anonymních úprav kýmkoliv) může být lepší pod článkem autora vůbec neuvádět, či čtenáře upozornit, co přesně je vlastní dílo autora (např́íklad odkazem na konkrétní verzi, kterou autor vytvořil, či poslední verzi, již zkontroloval).

\section{Uvádění recenzenta}

Podobně je tomu u uvedení recenzenta obsahu. Pokud finální obsah článku schválí odborník v daném oboru, může to výrazně zvýšit jeho kvalitu, a zejména využitelnost - z anonymního zdroje se podobně jako v případě uvedení autora stává zdroj neanonymní, navíc recenzovaný.

I zde je ale třeba opatrnosti v prrípadě možností dalších aktualizací, aby recenzent nebyl uveden pod verzí, již nerecenzoval. Dobrým příkladem jak toto vyřešit mohou být například „zelené fajfky”, které značí, že uvedená verze článku byla schválena odborníkem.

\section{Statistické údaje}

OER MWS navíc umožňují u každého uživatele (at' registrovaného, či s anonymním nickem) zobrazit celkovou historii jeho editací od začátku jeho působení, včetně poměru jeho úspěšných a neúspěšných editací. Poměr počtu úspěšných editací (t.j. editací, které nebyly nikým jiným vráceny) je pak docela jednoduchým indikátorem ocenění práce autora komunitou daného zdroje; zvláště vynikne v případě anonymního uživatele, kdy tato metrika alespoň nějak umožňuje hodnotit jeho práci (viz Obrázek 10).

Obrázek 10. Údaje o uživateli anglické Wikipedie s různými metrikami zaznamenávajícími jeho aktivitu. Údaj o úspěšných editacích (Live edits) je vyznačen červeně. 


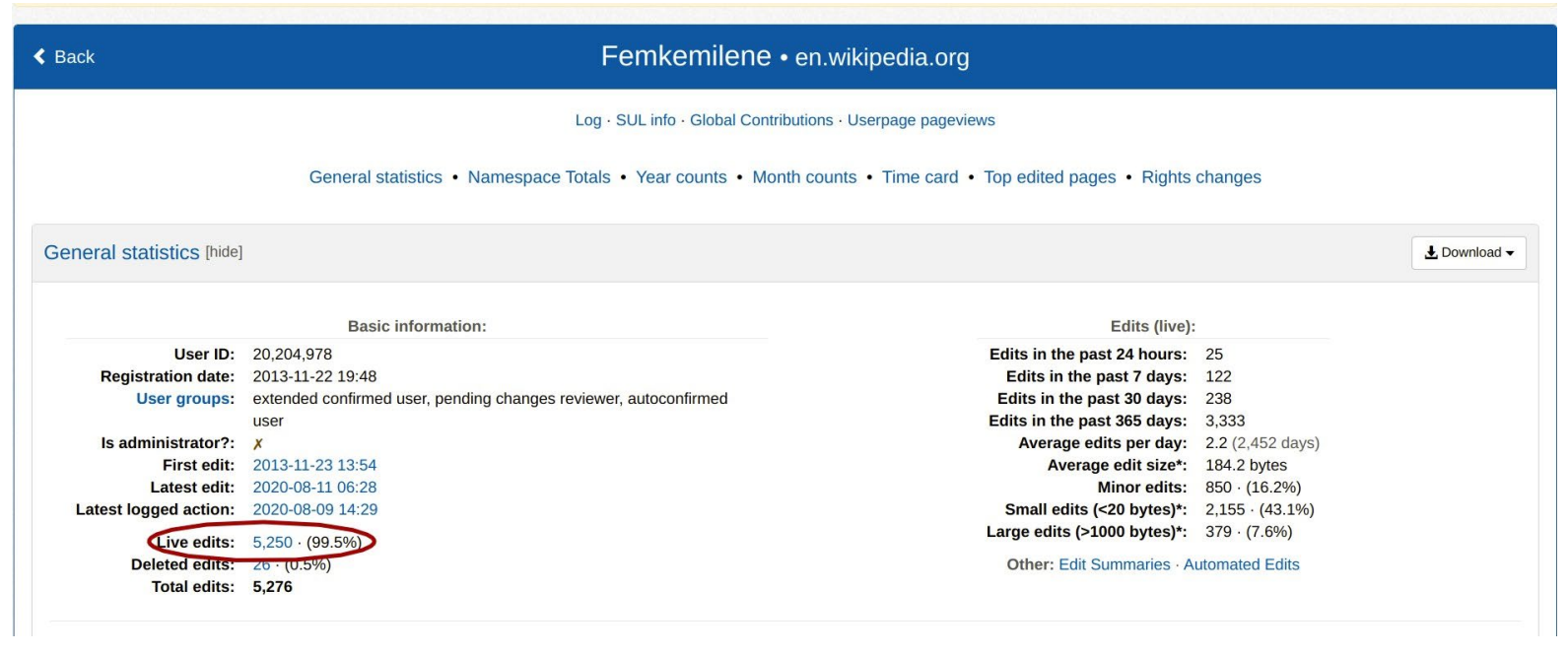

\section{Kvalita obsahu}

Problémy se zajištěním kvality patří mezi největší výzvy v oblasti vytváření a údržby OER MWS. Právě otázka kvality je tím, co ztěžuje přijetí těchto zdrojů jako respektovaných studijních materiálů. Posuzování kvality však mohou ulehčit například kritéria kvality, jimiž je možné dané zdroje evaluovat (viz dále část Procesy zajištění kvality).

\section{Garant kvality}

V prostředí OER MWS bývá kvalita garantována komunitou, nikoliv odborníkem jako $\checkmark$ prípadě klasických tištěných či elektronických zdrojů. $V$ př́padě vytváření materiálů např. pro vysokoškolské účely může být ale také komunitní recenzování doplněno expertním posouzením. OER MWS umožňuje formou jednoduché šablony přiřadit ke každému obsahu jak autora, tak recenzenta. $V$ tomto prípadě je ale třeba mít na vědomí, že jednou recenzovaný text se může $v$ průběhu času značně změnit a recenzent či autor tak může být následně uveden i pod značně odlišnou verzí, než byla ta, kterou schválil. To se dá ošetřit např́íklad uvedením verze, kterou expert naposledy posoudil (např. již zmíněným grafickým znázorněním „zelené fajfky”) a upozorněním, že stávající verze nebyla zkontrolována.

\section{Vnímání kvality}

Otevřené vzdělávací zdroje, které fungují na bázi MediaWiki softwaru, se často potýkají s předsudky týkajícími se jejich kvality. $\mathrm{V}$ tomto ohledu je nejčastěji diskutovaná Wikipedie, která čelí značné nedůvěře zejména v akademickém prostředí. Tato kritika bývá často oprávněná vzhledem k tomu, že OER MWS nemají často garanta textu jako celku, jako tomu bývá v případě klasických učebnic, skript či odborných publikací. Na druhou stranu je i zde možné kvalitu ošetřit správně nastavenými procesy. Uživatel těchto zdrojů by měl být ale 
patřičně upozorněn na procesy, kterými je u daných zdrojů kvalita ošetřena, stejně jako na př́ípadná rizika, s kterými se může setkat. Obecně tento typ klade na uživatele větší nároky ve smyslu rozpoznávání a hodnocení kvality. Čtenář se stává zároveň arbitrem této kvality a v prípadě nedostatků může zdroj také upravit, a pomoci mu tak zvýšit kvalitu.

\section{Rozpoznání kvality}

Rozpoznávání kvality obsahu OER MWS je komplexní aktivita, při které je vhodné vzít v potaz více faktorů. Kromě klasických aspektů, jako je autorita vydavatele, je možné posoudit i kvalitu aktuálnosti (přes zobrazení historie) či strukturu a čtivost jednotlivých materiálů. Někteří tvůrci používají i algoritmus pro zhodnocení uživatelské přívětivosti textu ve smyslu čtenosti (např. v př́padě WikiSkript tzv. Mistríkovo skóre čtivosti).

U zdrojů na bázi MediaWiki softwaru hrají také značnou roli reference a důkladná ozdrojovanost jednotlivých pasáží. Dưraz na citování zdrojů by měl být větší než v prípadě klasických tištěných či elektronických zdrojů, u nichž je dán garant kvality u finální podoby. V př́padě volně modifikovatelných terciálních zdrojů je totiž právě důsledné citování primárních a sekundárních pramenů tím, co pomáhá zvyšovat kvalitu zdroje. Určitým garantem kvality tak jsou i publikace, $v$ nichž jsou uvedené informace obsaženy.

\section{Spolehlivost informací}

Spolehlivost informací garantuje komunita zdroje prostřednictvím citování respektovaných zdrojů informací pro daný obor. Hierarchie zdrojů se liší oborově, obecně ale platí, že $v$ prípadě vysokoškolského vzdělávání je patrný trend směřující $k$ využívání vědeckých publikací, jako jsou recenzované články v respektovaných časopisech. Používání primárních pramenů tam, kde je to možné, zvyšuje kvalitu výuky a pomáhá $\mathrm{k}$ diseminaci vědeckých poznatků $z$ akademického prostředí ke studentům a tím je učí i základům vědecké práce a metody. Vědecké poznání se ale rychle mění, proto je vhodné zdroje často aktualizovat nejnovějšími poznatky. K tomu mohou pomoci mladí profesionálové $\mathrm{z}$ praxe, pokud se do vytváření těchto zdrojů zapojí již v průběhu studia a pokračují v nich při své profesi. Ukázkovým př́kladem jsou rovněž WikiSkripta, kde tuto roli plní mladí lékaři připravující se na atestace, kteří mají aktuální znalosti ze svých oborů.

\section{Aktuálnost informací}

Zajištění aktuálnosti informací je hlavní devízou, kterou zdroje na bázi MediaWiki softwaru mají oproti klasickým publikačním schématům, a zároveň představuje značnou výzvu, co se týče udržitelnosti zdroje. Pro zajištění aktuálnosti zdroje je stěžejní komunita, která jej spravuje. Pokud informace nejsou pravidelně aktualizovány, prostředí wiki již 
nefunguje tak, jak by mělo, a obsah zdroje upadá. To platí také o URL adresách, na které zdroj odkazuje a které jsou důležité pro ověřitelnost informací. Pokud nejsou tyto adresy pravidelně aktualizovány, stává se řada odkazů po čase nefunkčními.

\section{Percepce kvality studenty}

Ukazuje se, že pro studenty se stává dohledatelnost informací hlavním kritériem při výběru studijních materiálů. OER MWS jsou díky své struktuře vyhledávači preferovány, často i na prvních prríčkách vyhledávání, a studenti je tedy často využívají. Vyhovuje jim také přehledná struktura, na kterou jsou zvyklí z Wikipedie, stejně jako možnosti jednoduchého přesměrování formou hyperlinků na související témata. Percepci kvality ze strany studentů a následné další využívání těchto zdrojů ale značně ovlivňuje také okolí studentů. Tedy to, zda jsou studentům tyto zdroje doporučeny pedadogy či staršími spolužáky, kterým již pomohly při plnění studijních povinností.

\section{Procesy zajištění kvality}

OER MWS nabízí širokou škálu možností a procesů pro zajištění kvality obsahu. Od částečného či úplného zamezení úprav jednotlivých svých částí přes software detekující nevhodný obsah, např. plagiarismus, až po klasické mechanismy zajišt'ování kvality, jakými jsou např. recenzní rízení či uvádění autorů. Pro zajištění kvality se u OER MWS dají použít různá kritéria (viz Tabulka 14).

Tabulka 14. Možná kritéria kvality využitelná pro OER fungující na bázi MediaWiki softwaru pro vysokoškolské účely a jejich popis

\section{Popis kritéria}

Vyznačení licence - Licencování zdroje pod otevřenou licencí je základní podmínkou, aby se zdroj dal označit a používat jako OER. Pokud je takto licencován, ale není to vyznačeno, ti, kteří to nevědí, ho takto využívat nemohou. Vyznačení licence u všech materiálů, které jsou pod otevřenou licencí (či $v$ rámci celého zdroje, pokud je celý pod otevřenou licencí), je proto důležité pro jejich šíření.

Datum vytvoření - Vyznačení data vytvoření zdroje je klíčovým znakem kvality pro jeho využívání, popř. citování v dalších zdrojích.

Datum poslední aktualizace - Vyznačení data poslední aktualizace je stejně jako vyznačení data vytvoření důležitým kritériem kvality.

Vyznačení verze stránky a historie editací - Pokud se má na zdroj odkazovat v odborné práci, je lepší citovat ID verze stránky než čas přístupu. Zdroj se totiž může aktualizovat velice rychle, zejm. v 
prípadě aktuálních událostí. Na Wikipedii mohou proběhnout dvě změny během jedné minuty.

Autorství - Reputace autora je důležitým kritériem kvality, a to jak v př́padě tištěných, tak online zdrojů. Právě vyznačení autorství je jedním z prvků, kterým se mohou různé projekty OER fungující na bázi MediaWiki softwaru odlišit od Wikipedie.

Recenze - Recenzní rízení je jedním z hlavních kritérií kvality v akademickém prostředí. Publikace recenzované relevantními odborníky jsou respektovány více než ty nerecenzované. Proto je ideální, když i OER určené pro VŠ účely umožňují recenzní rízení a jeho vyznačení (např. uvedením, že tento článek byl recenzován př́islušným odborníkem). Recenzní řízení u OER může zajistit editorský tým formou interního komunitního recenzování či oslovením externích expertů.

Vyznačení kvality tvưrci - Vyznačují u konkrétních OER tvưrci nějakým způsobem jejich kvalitu? Např. formou doporučení odborníků v dané oblasti?

Udržitelnost - Kritérium odpovídá na otázku, zda projekt funguje v současné době, nebo je již pouze online, ale bez údržby. Právě aktualizace OER o nejnovější poznatky je hlavní předností těchto zdrojů proti tradičním materiálům. Pokud v rámci projektu vznikly materiály, které již ale nejsou editovány a aktualizovány nejnovějšími poznatky, dá se předpokládat, že kvalita materiálů na něm stagnuje či se snižuje.

Vyváženost - Kritérium ukazuje, zda kvalita jednotlivých částí textů výrazně nekolísá, např. zda zdroj neobsahuje vedle částí dobře zpracovaných také partie chybné či neaktuální.

Hodnocení kvality uživateli - Toto kritérium značí možnost uživatelského hodnocení kvality materiálů. Poskytuje tvưrcům také zpětnou vazbu, zda zdroje, které vytváŕí, jsou vnímány uživateli jako kvalitní. Pomáhá tak zároveň průběžně analyzovat spokojenost cílové skupiny.

Struktura - Toto kritérium zkoumá, zda se text drží daného žánru, co do struktury. Napríklad v rámci Wikipedie: jak přesně se drží článek žánru encyklopedického hesla (a není esejem či komentářem). Podobně je tomu se strukturou jazyka, vyjadřování by mělo být krátké a výstižné.

\section{Rizikové faktory}

Zajištění kvality OER MWS se potýká také s problémy. Tím hlavním je zajištění dlouhodobé udržitelnosti zdroje, a to zejména po stránce personální - dobře fungující komunity. $\mathrm{K}$ tomu je zapotřebí vyvažovat odchod některých pracovníků přijetím nováčků. Projekt ale může značně ohrozit odchod iniciátora a vedoucího projektu v případě, že nemá následovníka. Mezi faktory, jež mohou odrazovat nově příchozí, patří jakákoliv uzavřenost zdroje (omezení možností do něj přispívat), tak i nucení k zapojení do jeho vytváření (i ve formě školních povinností). Ukazuje se, že komunity těchto zdrojů fungují nejlépe na 
dobrovolné spolupráci a možnostech široké otevřenosti, aby se do nich mohli zapojit i př́ípadní zájemci zvenčí.

\section{Technické parametry prostředí}

MediaWiki software poskytuje bohatou sadu základních funkcí a možnost rozšíření k zajištění dalších funkcí. Můžeme rozlišit několik aspektů (Wikipedia contributors, 2020):

\section{Internacionalizace a lokalizace}

Vzhledem $\mathrm{k}$ silnému důrazu na mnohojazyčnost $\mathrm{v}$ projektech Wikimedia se internacionalizaci a lokalizaci (globálnímu i lokálnímu nastavení) věnuje významná pozornost. Uživatelské rozhraní bylo zcela nebo částečně přeloženo do více než 300 jazyků (translatewiki.net).

\section{Instalace a konfigurace}

Instalace MediaWiki vyžaduje, aby uživatel měl administrátorská oprávnění na serveru provozujícím PHP i kompatibilní typ SQL databáze. Někteří administrátoři považují nastavení virtuálního hostitele za užitečné, pokud většina webu běží pod rámcem (například Zope nebo Ruby on Rails), který je do značné míry nekompatibilní s MediaWiki. Cloud hosting může eliminovat potřebu nasazení nového serveru.

\section{Úpravy rozhraní}

Aby se usnadnila editace dlouhých stránek, MediaWiki umožňuje editaci podsekce stránky (podle jejího záhlaví). Registrovaný uživatel může také označit, zda je úprava drobná. Oprava pravopisu, gramatiky nebo interpunkce je př́kladem drobných úprav, zatímco přidání odstavců nového textu je příkladem větší úpravy. Může také dojít k tomu, že jeden uživatel upravuje a současně druhý uživatel uloží úpravy do stejné části stránky. Když se první uživatel pokusí stránku uložit, dojde ke konfliktu verzí. V takovém případě může druhý uživatel sloučit svůj obsah do stránky, jež vznikne až po uložení úpravy prvního uživatele.

\section{Bohatý obsah}

MediaWiki podporuje bohatý obsah generovaný specializovanou syntaxí. Napríklad software je dodáván s volitelnou podporou pro vykreslování matematických vzorců pomocí LaTeXu a speciálního analyzátoru napsaného v OCaml. Podobná funkčnost pro další obsah, od grafických časových os přes matematické vykreslování a hudební skóre po egyptské hieroglyfy, je k dispozici prostřednictvím rozšíření. 


\section{Sledování úprav}

Mezi funkce MediaWiki, které pomáhají při sledování úprav, patří funkce Poslední změny, která poskytuje seznam posledních úprav wiki. Tento seznam obsahuje základní informace o těchto úpravách (uživatel, shrnutí úprav, upravovaná stránka), jakož i všechny značky (např. „Možný odkaz na malware“) přidané přizpůsobitelnými filtry, jež hlásí zneužití, a dalšími rozšířeními, která pomáhají v boji proti neužitečným úpravám.

\section{Navigace}

Navigace přes wiki probíhá převážně prostřednictvím interních wikilinků. Wikilinky MediaWiki implementují detekci existence stránky, ve které je odkaz modrý, pokud cílová stránka existuje na místní wiki, a červený, když tomu tak není. Jestliže uživatel klikne na červený odkaz, zobrazí se výzva k vytvoření článku s tímto názvem. Díky detekci existence stránky je pro uživatele praktické vytvářet „wikifikované“ články, to znamená články obsahující odkazy na jiné relevantní předměty, aniž by tyto ostatní články ještě existovaly.

\section{Organizace obsahu}

\section{Karty a související stránky}

Karty stránek se zobrazují v jejich horní části stránek. Umožňuji uživatelům provádět akce nebo prohlížet stránky, které se vztahují ke stránce aktuální. Dostupné výchozí akce zahrnují prohlížení, úpravy a diskuzi o této stránce.

\section{Jmenné prostory}

Jmenné prostory jsou předpony před názvem stránky (např́klad „User:“ nebo „Talk:“), které slouží jako popisovače pro účel stránky a umožňují, aby pod stejným názvem existovalo více stránek s různými funkcemi.

\section{Označení kategorií}

Uživatelé mohou vytvářet nové kategorie a vkládat stránky a soubory do nich, a to přidáním jedné nebo více značek kategorií do textu obsahu. Přidáním do kategorií se vytvoří odkazy ve spodní části stránky, které čtenáře přivedou na seznam všech stránek $v$ této kategorii, což usnadňuje procházení souvisejících článků.

\section{Skupiny a omezení př́ístupu}


MediaWiki nabízí flexibilitu při vytváření a definování skupin uživatelů. Je také možné nastavit skupinu „automaticky potvrzených uživatelů”, do nichž se uživatel zařadí po provedení určitého počtu úprav či fungování po určitém počtu dní. ${ }^{36}$

${ }^{36} \mathrm{~V}$ rámci MediaWiki softwaru mohou fungovat např́iklad různí roboti, kteří upozorňuji (či znemožňuji vkládání) na určitá slovní spojení jako vulgarismy či slova, u nichž hrozí zastarání (např́íklad ,tento rok"). 


\section{Závěr}

Cílem této metodiky bylo uvedení do problematiky otevřených vzdělávacích zdrojů na bázi Mediawiki softwaru (OER MWS) a poskytnutí metodického materiálu pro jejich vytváření a využívání. Nejprve jsme se věnovali konceptu otevřených vzdělávacích zdrojů, jejich definici a aspektům, jako jsou otevřené licence a problém kvality, shrnuli jsme také benefity a zápory prì aplikaci těchto zdrojů. Následně jsme se zabývali již specifiky OER MWS, upozornili jsme, že se jedná o specifický žánr textu, a prezentovali výsledky analýzy aktérů OER MWS. Pozornost byla věnována také využívání OER MWS. Poté jsme se již zaměřili na konkrétní zásady pro vytváření OER MWS. Na základě analýzy aktérů jsme představili doporučení a možnosti týkající se obsahové stránky, práce redakčního týmu či technických parametrů prostředí. Věnovali jsme se také problematice komunity a technickým parametrům prostředí. 


\section{Seznam použitých zkratek}

- MWS - MediaWiki software

- OER - otevřené vzdělávací zdroje

- OER MWS - otevřené vzdělávací zdroje na bázi Mediawiki softwaru 


\section{Seznam metodických výstupů přidružených $\mathrm{k}$ metodice}

- Analýza OER na UK a posuzování kvality - mapovací studie. (Interní materiál COŽP).

- Petiška, E., Korhoňová, L., Pospíšilová, M., \& Dlouhý, J. (2020). Využívání a posuzování kvality otevřených vzdělávacích zdrojů v kontextu vysokých škol: situace na Univerzitě Karlově. Envigogika, 15(1). (Recenzovaný článek).

- Portál: Otevřené vzdělávací zdroje. (Metodický portál na Enviwiki). ${ }^{37}$

- Př́íprava aplikační roviny a šetření využitelnosti v rámci kurzů. (Interní materiál COŽP).

${ }^{37} \mathrm{Na}$ němž byla také publikována část poznatků z metodiky za účelem zvýšení diseminace odborných poznatků. (Portál je k dispozici na webu www.enviwiki.cz - do vyhledávače na stránce stačí napsat „Portál:Otevřené vzdělávací zdroje”.) 


\section{Seznam dosavadních publikačních výstupů řešitelů v dané oblasti předcházející metodice}

- De Kraker, J., Dlouhá, J., Machackova Henderson, L., \& Kapitulcinová, D. (2017). The European virtual seminar on sustainable development as an opportunity for staff ESD competence development within university curricula. International Journal of Sustainability in Higher Education, 18(5), 758-771. https://doi.org/10.1108/IJSHE-03-2016-0040

- Dlouhá, Jana, Dlouhý, J., Kapitulčinová, D. (2016). Metodika tvorby a využití případových studií ve výuce a formou Open Educational Resources (OER). Certifikováno Ministerstvem životního prostředí ČR pod č.j. 7151/ EHV/ 16. Envigogika 11, č. 1 (6. duben 2016). https://doi.org/10.14712/18023061.515

- Dlouhá, J. a kol. (2012). Metodika tvorby textů v otevřeném internetovém prostoru. viz http://www.enviwiki.cz/wiki/Metodika tvorby text\%C5\%AF v otev\%C5\%99en\%C3\%A9 m internetov\%C3\%A9m prostoru (schváleno MŽP ČR 31.1.2012, pod č.j. 5782/ENV/12; 154/320/12)

- Dlouhá, J. (2008). EnviWiki - the Czech Multimedia Toolkit for Education for Sustainable Development (ESD). Envigogika, 3(1). [Online] [Citováno 2014-08-29]. ISSN: 1802-3061. DOI: $\underline{\text { http://dx.doi.org/10.14712/18023061.373 }}$

- Dlouhá, J., Barton, A., Litina-Papastathi, A., Pachmanová, L. (2011). Indicators for Reflection of Learning Processes in Sustainability Oriented Regional Networks of Cooperation. In: Barton, A., \& Dlouhá, J., (eds) Multi-Actor Learning for Sustainable Regional Development in Europe: A Handbook of Best Practice. Guildford: Grosvenor House Publishing Ltd; $2011 . \quad$ p. https://www2.ioer.de/recherche/pdf/2011 harfst multi-actor learning.pdf\#page=51

- Dlouhá, J., Burandt, S. (2015). Design and evaluation of learning processes in an international sustainability oriented study programme. In search of a new educational quality and assessment method. Journal of Cleaner Production, 106, 247-258. http://doi.org/10.1016/j.jclepro.2014.09.096

- Dlouhý, J., Dlouhá, J. Metodika využití Wiki (Wiki - metodika). viz. http://www.enviwiki.cz/wiki/Wiki - metodika (schváleno MŽP ČR 31.1.2012 pod č.j. 5782/ENV/12; 154/320/12).

- Dlouhý, J., Dlouhá, J. (2011). Výuka v otevřeném virtuálním prostoru - Wikipedie, nebo vlastní wiki? In Sborník 7. ročníku konference o elektronické podpoře výuky SCO 2011. : 2011. s. 81-86 ISBN 978-80-210-5528-5 
- Dlouhý, J., Dlouhá, J. (2012). Wiki strategies for a more participatory learning environment in Czech education. 11th European Conference on e-Learning ECEL-2012, University of Groningen, Groningen, The Netherlands, 26-27 October 2012,

- Dlouhá, J., Dlouhý, J., Barton, A. (2011). E-learning Methodology for Regional Cooperation and Promotion of the European Learning Space in the Interdisciplinary Field of Sustainable Development. In: Barton, A., \& Dlouhá, J., (eds) Multi-Actor Learning for Sustainable Regional Development in Europe: A Handbook of Best Practice. Guildford: Grosvenor House Publishing Ltd; 2011. pp. 81-105

- Dlouhá, J., Dlouhý, J., Barton, A. Evaluating educational Outcomes in the Interdisciplinary Field of Sustainable Development: Case Study of an E-learning Course in an Interactive (Open) Virtual Space. Knowledge Collaboration \& Learning for Sustainable Innovation \& ERSCP-EMSU conference, Delft, The Netherlands, October 25-29, 2010

- Dlouhá, J., Dlouhý, J., Barton, A. Use of Web 2.0 Tools for Active Learning Strategies in the Interdisciplinary Field of Sustainable Development: Analysis of Communicative Aspects of Interactive (Open) Virtual Spaces. Engineering Education in Sustainable Development 201019 - 22 September, Goteborg

- Dlouhá, J., Dlouhý, J., Macháčková Henderson, L., Zahradník, M. Wiki Software and Educational Principles of Communicative Action. Case study of the Czech electronic environmental encyclopedia (EnviWiki). E-learning conference: Boundary Changes: Redefining Learning Spaces, April 23-24, 2009, University of Plymouth, GB, Dostupné na: http://www2.plymouth.ac.uk/e-learning/conference programme 2009.pdf

- Dlouhá, J., Dlouhý, J., Pachmanová, L. E-learning na bázi spolupráce dvou elektronických prostředí - LMS a wiki. Využití EnviWiki, elektronické encyklopedie o životním prostředí, ve vysokoškolské výuce. In: Sojka, P., Rambousek, J. (ed.) Sborník 6. ročníku konference o elektronické podpoře výuky SCO2009. Brno, MUNIpress. 2009, ss. 238-243. ISBN 97880-210-4878-2

- Dlouhá, J., Dlouhý, J., Zahradník, M. (2011). Procesy a přístupy k učení - hodnocení práce studentů ve wiki prostředí. In Sojka, P., Kvizda, M. (eds.) Sborník 7. ročníku konference o elektronické podpoře výuky SCO 2011. : 2011. s. 75-80. ISBN 978-80-2105528-5

- Dlouhá, J., Macháčková-Henderson, L., \& Dlouhý, J. (2013). Learning networks with involvement of higher education institutions. Journal of Cleaner Production, Volume 49, June 2013, pp. 95-104, http://dx.doi.org/10.1016/j.jclepro.2012.06.009

- Dlouhá, J., Petiška, E., Dlouhý, J., \& Kapitulčinová, D. (2015). Opportunities and Risks of the Use of Open Education Resources in Environmental Disciplines at University Level in the Czech Republic: A Criteria for Assessing Quality. Envigogika, 10(4). https://doi.org/10.14712/18023061.503 
- Dlouhá, J., Zahradník, M., Dlouhý, J., Barton, A. (2011). Tools for Evaluating Students' Work in an Interactive (Open) Virtual Space: Case Study of an E-Learning Course in an International Network of Universities. Proceedings of the 10th European Conference on E-learning, Vols 1 and 2 Pages: 166-176 Published: 2011. WOS:000300244000021

- Dlouhá, Marie. (2011). Autorita ve virtuálním vzdělávání. Envigogika 2011/VI/2. https://doi.org/10.14712/18023061.60

- Kapitulčinová, D., Spustová, K., Nemcová, M., Petiška, E., \& Dlouhá, J. (2015). Analýza využívání termínu Open Educational Resources na českých vysokých školách $v$ mezinárodním kontextu. Aula, 23(2), 29-48.

- Petiška, E. (2018). Využívání otevřených vzdělávacích zdrojů studenty environmentálních oborů v České republice. Envigogika, 13(1). https://doi.org/10.14712/18023061.548

- Petiška, E. (2018). Spíše Wikipedie než učebnice: Vzorce využívání otevřených vzdělávacích zdrojů studenty environmentálních oborů. Envigogika, 13(2). https://doi.org/10.14712/18023061.569

- Petiška, E. (2018). Otevřené vzdělávací zdroje: podpora tvưrcům otevřených vzdělávacích materiálů. Praha: Ústřední knihovna Univerzity Karlovy.

- Petiška, E. (2020). Otevřené vzdělávací zdroje v kontextu environmentálních studií. Praha. 126 stránek. Disertační práce. Univerzita Karlova, Fakulta humanitních studií, Centrum pro otázky životního prostředí. Vedoucí disertační práce Richard Papík. https://dspace.cuni.cz/handle/20.500.11956/117555

- Petiška, E.; Dlouhá, J. (2018). Zajištění kvality otevřených vzdělávacích zdrojů: jak správně vytvářet a využívat volně dostupné studijní materiály pro vysokoškolské účely. Zdůvodnění potřebnosti projektu.

- Petiška, E., \& Moldan B. (2019). Indicator of Quality for Environmental Articles on Wikipedia at the Higher Education Level. Journal of Information Science, OnlineFirst. https://doi.org/10.1177\%2F0165551519888607

- Petiška, E., Pospíšilová M., Korhoňová L. Dlouhý, J. (2020). Využívání a posuzování kvality otevřených vzdělávacích zdrojů v kontextu vysokých škol: situace na Univerzitě Karlově. Envigogika 15(1). https://doi.org/10.14712/18023061.607

- Zahradník, M., Dlouhá, J. (2016). Metodika analýzy aktérů (Actor analysis methodology). Certifikováno Úřadem vlády ČR pod č.j. 9645/2016-OUR. Envigogika 11, č. 1 (1. květen 2016). https://doi.org/10.14712/18023061.527

- Zahradník M., Pachmanová L. (2009). Příklad využití wiki-prostředí v environmentálním vzdělávání na vysoké škole: hodnocení kurzu Organizace a řízení v ochraně životního prostředí. Envigogika 2009/IV/3 https://doi.org/10.14712/18023061.46 


\section{Literatura}

\section{Seznam použité literatury}

Alkhattabi, M., Neagu, D., \& Cullen, A. (2010). Information quality framework for elearning systems. Knowledge Management \& E-Learning, 2(4), 340-362.

https://doi.org/10.34105/j.kmel.2010.02.025

Analýza OER na UK a posuzování kvality - mapovací studie. (Interní dokument COŽP).

Belikov, O. M., \& Bodily, R. (2016). Incentives and barriers to OER adoption: A qualitative analysis of faculty perceptions. Open Praxis, 8(3), 235-246.

https://search.informit.org/doi/abs/10.3316/informit.283536367861626

Campus Computing Project. (2015). “The 2015 Campus Computing Survey”, Dostupné na: http://www.campuscomputing.net/page/kenneth-c-green-director (Dostupné 30. 1. 2018).

Cohen, Noam. (2020). How Wikipedia Prevents the Spread of Coronavirus

Misinformation. Wired. https://www.wired.com/story/how-wikipedia-prevents-spreadcoronavirus-misinformation/ (Dostupné 9. 2. 2021).

Dlouhá, J., Petiška, E., Dlouhý, J., \& Kapitulčinová, D. (2015). Možnosti a rizika využití otevřených vzdělávacích zdrojů v environmentálních oborech na vysokoškolské úrovni v ČR: kritéria pro posouzení kvality. Envigogika, 10(4).

https://doi.org/10.14712/18023061.503

Dukić, D., \& Strišković, J. (2015). Croatian university students' use and perception of electronic resources. Library \& Information Science Research, 37(3), 244-253.

https://doi.org/10.1016/j.lisr.2015.04.004

Eaton S.E. (2018). Educational Research Literature Reviews: Understanding the Hierarchy of Sources. Calgary: University of Calgary, http://hdl.handle.net/1880/106406 (přístupné 24. 10. 2019).

Fischer, L., Hilton, J., Robinson, T. J., \& Wiley, D. A. (2015). A multi-institutional study of the impact of open textbook adoption on the learning outcomes of post-secondary students. Journal of Computing in Higher Education, 27(3), 159-172.

https://doi.org/10.1007/s12528-015-9101-x 
Hewlett Foundation. OER Defined. https://hewlett.org/strategy/open-educationalresources/ (Dostupné 12. 2. 2021).

Hilton, J. (2016). Open educational resources and college textbook choices: a review of research on efficacy and perceptions. Educational Technology Research and Development, 1-18. https://doi.org/10.1007/s11423-016-9434-9

Hylén, J. (2006). "Open educational resources: Opportunities and challenges", http://ubir.bolton.ac.uk/290/1/iec reports-1.pdf (Dostupné 30. 1. 2018).

ITU. (2015). WSIS - SDG Matrix Linking WSIS Action Lines with Sustainable Development Goals. https://www.itu.int/net4/wsis/sdg/

Jemielniak, D. (2019). Wikipedia: Why is the common knowledge resource still neglected by academics?. GigaScience, 8(12). https://10.1093/gigascience/giz139

Onaifo, Daniel. (2016). "Alternate Academy: Investigating the Use of Open Educational Resources by Students at the University of Lagos in Nigeria" . Electronic Thesis and Dissertation Repository. 4086.

http://ir.lib.uwo.ca/cgi/viewcontent.cgi?article=5467\&context=etd

Národní ústav pro vzdělávání. (2016). https://clanky.rvp.cz/wpcontent/upload/prilohy/21071/kriteria kvality digitalnich vzdelavacich zdroju.pdf (Dostupné 21. 1. 2019)

Petiška, E. (2018a). Využívání otevřených vzdělávacích zdrojů studenty environmentálních oborů v České republice. Envigogika, 13(1).

https://doi.org/10.14712/18023061.548

Petiška, E. (2018b). Spíše Wikipedie než učebnice: Vzorce využívání otevřených vzdělávacích zdrojů studenty environmentálních oborů. Envigogika, 13(2).

https://doi.org/10.14712/18023061.569

Petiška, E. (2018c). Otevřené vzdělávací zdroje: podpora tvůrcům otevřených vzdělávacích materiálů. Praha: Ústřední knihovna Univerzity Karlovy.

Petiška, E. (2020). Otevřené vzdělávací zdroje v kontextu environmentálních studií. Praha. 126 stránek. Disertační práce. Univerzita Karlova, Fakulta humanitních studií, Centrum pro otázky životního prostředí. Vedoucí disertační práce Richard Papík. (v textu jsou použity úryvky z práce). https://dspace.cuni.cz/handle/20.500.11956/117555 
Petiška, E.; Dlouhá, J. (2018). Zajištění kvality otevřených vzdělávacích zdrojů: jak správně vytvářet a využívat volně dostupné studijní materiály pro vysokoškolské účely. (Zdůvodnění potřebnosti projektu - Interní materiál COŽP).

Petiška, E., \& Moldan B. (2019). Indicator of Quality for Environmental Articles on Wikipedia at the Higher Education Level. Journal of Information Science, OnlineFirst. https://doi.org/10.1177\%2F0165551519888607

Petiška, E., Pospíšilová M., Korhoňová L. Dlouhý, J. (2020). Využívání a posuzování kvality otevřených vzdělávacích zdrojů v kontextu vysokých škol: situace na Univerzitě Karlově. Envigogika 15(1). https://doi.org/10.14712/18023061.607

Petiška, E., Kuběna, A. \& Moldan, B. (v publikačním procesu). What does the analysis of 7,048 environmental articles tell us about the perception of Wikipedia's quality? $V$ prípravě.

Politika otevřených vzdělávacích zdrojů. (2016).

https://www.enviwiki.cz/w/index.php?title=Politika otev\%C5\%99en\%C3\%BDch vzd\%C4 \%9BI\%C3\%A1vac\%C3\%ADch zdroj\%C5\%AF\&oldid=19337 (Dostupné 7. 6. 2018, ID stránky: 19337).

Přispěvatelé Wikipedie. (2018). Základní principy. Wikipedia, The Free Encyclopedia. https://meta.wikimedia.org/wiki/Founding_principles/cs (Dostupné 9. 4. 2018).

Přispěvatelé Wikipedie. (2021). Wikipedia:Content assessment. Wikipedia. (Dostupné 12. 2. 2021, ID stránky: 924080103$)$.

https://en.wikipedia.org/wiki/Wikipedia:Content assessment

Rohs, M., \& Ganz, M. (2015). MOOCs and the claim of education for all: A disillusion by empirical data. The International Review of Research in Open and Distributed Learning, 16(6). https://doi.org/10.19173/irrodl.v16i6.2033

Stiglitz, J. E. (1999). Knowledge as a global public good. Global public goods: International cooperation in the 21st century, 308, 308-25.

TES Global. (2016). "Three in Four U.S. Teachers Say Open Educational Resources Are Used More Often Than Textbooks." https://www.haptic.ro/three-four-u-s-teachers-sayopen-educational-resources-used-often-textbooks/ 
Thompson, N., \& Hanley, D. (2018). Science is shaped by wikipedia: Evidence from a randomized control trial.

https://scholar.google.cz/scholar?cites $=1936918864128226801 \&$ as $\mathrm{sdt}=2005 \&$ sciodt $=0$, $\underline{5 \& \mathrm{hl}=\mathrm{CS}}$

Wikimediafoundation. (2020). Instagramový účet.

Wikipedia contributors. (2020). MediaWiki. Wikipedia, The Free Encyclopedia. https://en.wikipedia.org/w/index.php?title=MediaWiki\&oldid=972194887 (Dostupné 11. 8. 2020, ID stránky: 323 710).

Wiley, D., Bliss, T. J., \& McEwen, M. (2014). Open Educational Resources: a review of the literature. In Handbook of research on educational communications and technology (781-789). New York: Springer. https://doi.org/10.1007/978-1-4614-3185-5 63

Wineburg, S., McGrew, S., Breakstone, J., \& Ortega, T. (2016). Evaluating Information: The Cornerstone of Civic Online Reasoning. https://purl.stanford.edu/fv751yt5934

Zahradník, M., Dlouhá, J. (2016). Metodika analýzy aktérů (Actor analysis methodology). Certifikováno Úřadem vlády ČR pod č.j. 9645/2016-OUR. Envigogika 11, č. 1 (1. květen 2016). doi:10.14712/18023061.527. https://doi.org/10.14712/18023061.527

Yaari E, Baruchson-Arbib S; Bar-Ilan J. (2011). Information quality assessment of community generated content: A user study of Wikipedia. Journal of Information Science 2011; 37(5): 487-498. https://doi.org/10.1177\%2F0165551511416065 